
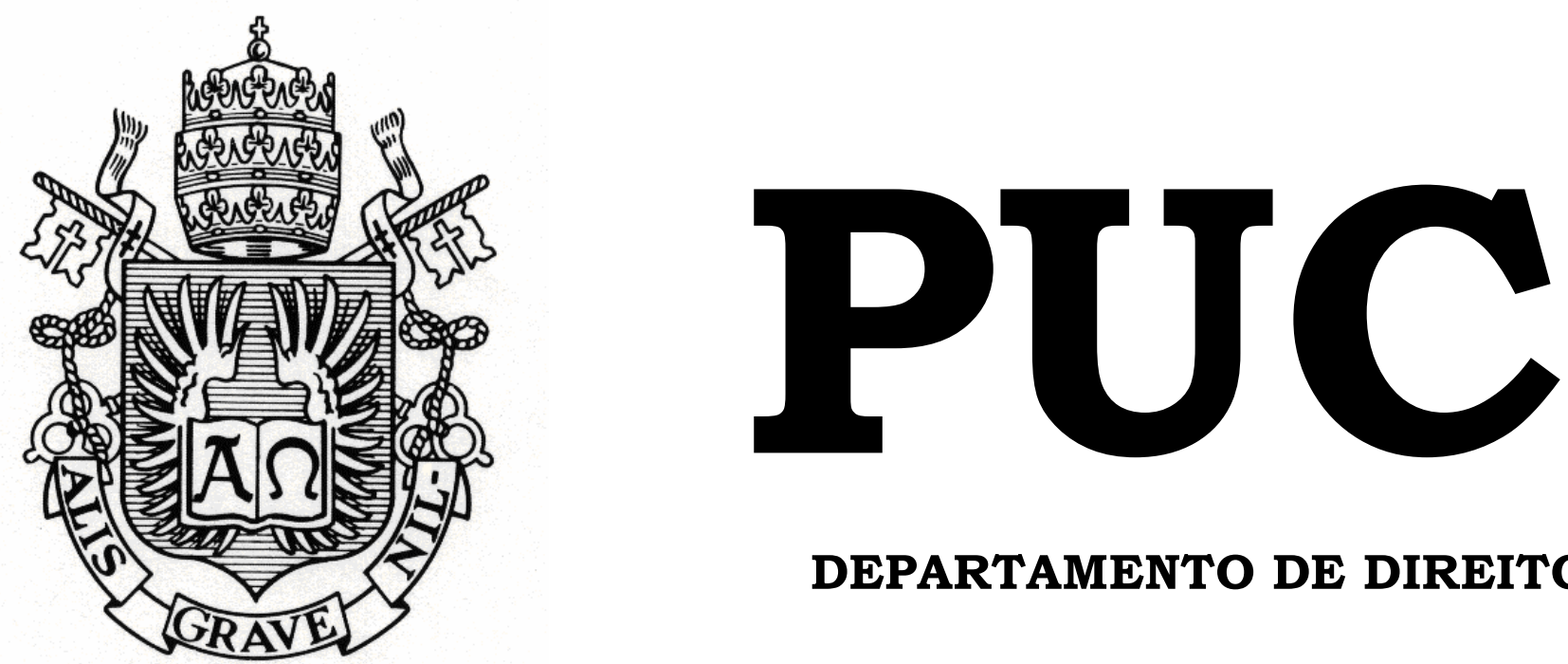

DEPARTAMENTO DE DIREITO

\title{
ARBITRAGEM NOS CONTRATOS ADMINISTRATIVOS
}

por

SILVIA FONTENELLE DUMANS CANETTI

ORIENTADORA: Nadia de Araujo

2007.2

PONTIFÍCIA UNIVERSIDADE CATÓLICA DO RIO DE JANEIRO

RUA MARQUÊS DE SÃO VICENTE, 225 - CEP 22453-900

RIO DE JANEIRO - BRASIL 


\title{
ARBITRAGEM NOS CONTRATOS
}

\section{ADMINISTRATIVOS}

\author{
por
}

\section{SILVIA FONTENELLE DUMANS CANETTI}

\author{
Monografia \\ apresentada \\ ao \\ Departamento de Direito da Pontificia \\ Universidade Católica do Rio de Janeiro \\ (PUC-Rio) para a obtenção do Título de \\ Bacharel em Direito.
}

Orientadora: Nadia de Araujo 
Ao meu pai Eli Bensoussan Canetti que com uma pergunta singela fez despertar meu interesse pelo tema. 


\section{Agradecimentos}

Aos que me ajudaram neste trabalho e contribuíram para sua elaboração, direta ou indiretamente, meus sinceros agradecimentos e eterna gratidão, em especial:

Aos meus pais, Suzana e Eli, por todas as oportunidades que me proporcionaram e pelo exemplo a ser seguido.

À minha irmã, Elisa, pelo apoio incondicional.

Aos amigos, por todos os momentos de descontração.

Ao meu namorado, Guilherme, pelo incentivo e paciência por todos os momentos roubados.

Ao Paulo Pessoa, amigo de todas as horas, independente de onde esteja, pela ajuda quando mais precisei.

À amiga Sara Nogueira por dividir comigo os altos e baixos da elaboração de um trabalho monográfico.

À minha orientadora Nadia de Araujo, por toda a confiança depositada em mim.

À Patrícia Regina Pinheiro Sampaio, pelas sugestões de bibliografia que enriqueceram este trabalho. 


\section{Resumo}

O presente trabalho se propõe a estudar a validade da arbitragem como meio de solução de controvérsias em contratos administrativos. Para tanto, aborda a temática da arbitragem de direito privado à luz da doutrina e jurisprudência brasileira, com o intuito de demonstrar as vantagens oferecidas por este instituto. Em seguida, trata de alguns aspectos do direito administrativo, incluindo determinados princípios que norteiam a atuação do Estado e as peculiaridades do contrato administrativo. Por fim, demonstra que a via arbitral não só é compatível com as questões envolvendo direitos patrimoniais disponíveis da Administração Pública, mas também contribui para a concretização do interesse coletivo em assegurar uma solução rápida e eficiente para os litígios. Apresenta, ainda, caso do Museu Guggenheim, para ilustrar a aplicabilidade prática do tema abordado.

Meios alternativos de solução de controvérsias

Arbitragem

Lei $n^{\circ}$ 9.307/96

Contrato administrativo 


\section{Abstract}

This paper intends to study the possibility of submitting to arbitration disputes related to administrative contracts. Hence, private arbitration is analyzed based on Brazilian jurisprudence and doctrine in order to demonstrate the advantages brought by the use of such institution. Additionally, the idea of Public Administration is explored, namely certain principles which guide governmental action and unique aspects of contracts executed by a State. Finally, it shows that arbitration is not only compatible with issues involving alienable rights of a State, but also contributes to put a rapid and efficient end to conflicts - which is definitely a matter of primary public interest. The case of the Guggenheim Museum, commented herein, illustrates the practical relevance of the theme.

Alternative dispute resolution mechanisms

Arbitration

Law n 9.307/96

Administrative contract 


\section{Sumário}

Introdução

\section{Arbitragem}

$\begin{array}{ll}1.1 \text { Considerações gerais } & 13\end{array}$

$\begin{array}{ll}1.2 \text { Vantagens que a arbitragem apresenta } & 14\end{array}$

$\begin{array}{ll}1.3 \text { Arbitragem de direito privado no Brasil } & 16\end{array}$

1.3.1 Histórico da arbitragem no país 17

$\begin{array}{ll}\text { 1.3.2 A Lei de Arbitragem } & 19\end{array}$

\section{Administração Pública}

2.1 Conceito 26

2.2 Princípios da Administração 27

2.3 Atos administrativos $\quad 30$

2.4 Contratos administrativos 32

\section{Arbitragem nos contratos administrativos}

3.1 Caso do Museu Guggenheim 37

3.1.1 Arbitrabilidade $\quad 39$

3.1.2 Interesse coletivo e interesse da Administração Pública 41

3.1.3 Confidencialidade e princípio da publicidade 43

3.1.4 Foro legal exclusivo e instância arbitral 45

3.1.5 Ausência de autorização legislativa específica 47

3.1.6 Inafastabilidade da jurisdição estatal 48

3.1.7 A boa-fé e a vedação do venire contra factum proprium 52

3.1.8 Alcance da decisão

$\begin{array}{lr}\text { Conclusão } & 55\end{array}$

$\begin{array}{lr}\text { Bibliografia } & 59\end{array}$ 


\section{Introdução}

Há muito, desde a metade do século XX, a civilização está evoluindo com uma nova economia caracterizada pela velocidade e volatilidade, com mudanças constantes que dificultam, quando não impossibilitam, qualquer previsibilidade. Em que pese as soluções trazidas pelo progresso econômico e pelas novas tecnologias, introduziu-se também um mundo de incertezas. Valores, outrora absolutos, cederam ao relativismo que domina não só a ciência, mas também o direito. Conceitos e fórmulas consolidadas em tantas decisões judiciais proferidas até então são abandonadas ou alteradas, enquanto outros mecanismos e princípios permanecem inalterados. Com isso, intérpretes e operadores do direito tentam conciliar o antigo direito com as novas necessidades sociais e econômicas, mantendo aquilo considerado útil e substituindo o obsoleto.

Mais recentemente, o desencadeamento do processo de globalização, aliado aos efeitos da tecnologia e da informatização, da economia mundial em rede e da interdependência complexa trazem à tona um conjunto de fatores e situações desconhecidas, que provocam novos relacionamentos não só entre indivíduos de diferentes nacionalidades, mas também entre autores estatais, supranacionais e transnacionais. Consequentemente, se torna imperativa a construção de novos paradigmas normativos e doutrinários.

O mundo dos negócios deparou-se com um novo desafio: garantir a previsibilidade dos efeitos de um ajuste firmado entre as partes. Em um contrato, as partes pretendem cristalizar e especificar os termos do acordo, para que tenham força de lei entre elas, visando a mitigar eventuais discordâncias futuras. Entretanto, não se parte mais da premissa vigente no passado, de que era possível prever e regulamentar tudo. A capacidade 
humana de previsão não se compara à possibilidade do surgimento de novas controvérsias, que são infinitamente maiores. Nada impede, portanto, que surjam divergências a respeito de situações não previstas, da interpretação de cláusulas contratuais ou mesmo de normas legais aplicáveis ao contrato.

Enquanto o mundo dos negócios encontra-se em uma fase de transformação contínua e dinamismo extraordinário, o Poder Judiciário se mostra incapaz de acompanhar tal realidade. Tendo diante de si uma legislação que por vezes reflete necessidades de décadas atrás, leva-se anos aguardando a análise dos doutrinadores e a manifestação jurisprudencial dos tribunais sobre questões mais atuais e até então desconhecidas. Assim, o direito positivo procura estabelecer mecanismos cada vez mais aperfeiçoados para a composição dos litígios, em prol da paz e da segurança jurídica, por meios que apresentem os requisitos da celeridade e da efetiva realização da justiça ${ }^{1}$.

Eis que ressurge, nesse contexto, o instituto da arbitragem em contraposição à relativa rigidez das leis, em face à crescente necessidade de flexibilização no âmbito negocial. A arbitragem se apresenta como um procedimento sob medida para garantir a interpretação e a aplicação das regras escolhidas pelas partes, como também a manutenção e gestão do contrato. Possibilita, ainda, a continuação de um diálogo harmônico entre as partes contratantes visando à execução e conclusão do contrato. Como apontado por Arnoldo $\mathrm{Wald}^{2}$, trata-se de "um instrumento de paz duradoura".

Embora fosse conhecida no Brasil desde o Império, até a edição da Lei $n^{\circ} 9.307 / 96$ a arbitragem era quase letra morta em nosso ordenamento

\footnotetext{
1 DALlARI, Adilson Abreu. Arbitragem na concessão de serviço público. In: Revista de Informação Legislativa. $\mathrm{n}^{\circ}$ 128. Brasília: [s.n], out./dez. 1995, p. 63

2 WALD, Arnoldo. A evolução do direito e a arbitragem. In: LEMES, Selma Ferreira; CARMONA, Carlos Alberto; MARTINS, Pedro Batista (coord.). Arbitragem: estudos em homenagem ao Prof. Guido Fernando da Silva Soares. São Paulo: Atlas, 2007. p. 461
} 
jurídico. Com o advento da referida lei, verificou-se a abertura de um novo espaço para a arbitragem como meio alternativo de solução de litígios no plano interno do Direito brasileiro. Plano esse até então marcado por um ordenamento enraizado no positivismo, que enfatizava a sobrevalorização das fórmulas escritas, aliado ao estatismo, que ampliava significativamente o papel do Estado, e ainda uma processualística que ainda hoje remonta a Franz Kafka, entre outros equívocos ${ }^{3}$. Desse quadro resultava a confusão entre o monopólio da jurisdição e o monopólio da justiça que por décadas impediu o desenvolvimento do procedimento arbitral no país.

Transcorrida mais de uma década de vigência da Lei de Arbitragem, a jurisprudência brasileira tem sido fértil em matéria de arbitragem ${ }^{4}$. As decisões dos tribunais indicam uma postura condizente ao consenso internacional. Hoje na maioria das situações envolvendo pessoas físicas e jurídicas de Direito privado, o Judiciário adota uma posição a favor da arbitragem. Consequiência disto é a crescente previsibilidade e segurança aos que participam do comércio internacional, bem como àqueles que desejam investir no país.

Apesar dos avanços logrados desde a edição da Lei de Arbitragem, há ainda muito a se aprender sobre o assunto. Nesse contexto, o presente estudo tem como objetivo estudar a validade do pacto arbitral em contratos administrativos. Trata-se de uma das questões mais polêmicas em se tratando de arbitragem, que tem suscitado decisões contraditórias. Sua importância reside no fato de que as novas formas de parceria entre o Estado e os particulares exigem a flexibilização da relação contratual,

\footnotetext{
${ }^{3}$ MOREIRA NETO, Diogo de Figueiredo. Mutações do direito administrativo. $3^{\mathrm{a}}$ ed. rev. e ampl. Rio de Janeiro: Renovar, 2007. p. 273

4 SANTOS, Mauricio Gomm Ferreira dos. Existe um consenso internacional no âmbito da arbitragem comercial? Está o Brasil em linha com tal consenso? In: LEMES, Selma Ferreira; CARMONA, Carlos Alberto; MARTINS, Pedro Batista (coord.). Arbitragem: estudos em homenagem ao Prof. Guido Fernando da Silva Soares. São Paulo: Atlas, 2007. p. 421
} 
priorizando o interesse das partes, mormente no que diz respeito à solução de controvérsias de modo mais rápido e eficaz.

Desta forma, inicialmente, se realiza um estudo sobre a arbitragem. Diferencia-se brevemente a arbitragem pública da privada, somente com o intuito de estabelecer que a primeira não interessa ao presente estudo. Em seguida, são apresentadas as vantagens que a arbitragem oferece como meio alternativo de solução de controvérsias e que justificam sua adoção em larga escala mundo afora. A partir daí, é traçado o histórico do instituto no Brasil, que culmina com o advento da Lei de Arbitragem. A este diploma legal é reservado um tópico específico, no qual se incluem as inovações por ele trazidas.

Em seguida, dedica-se um capítulo à temática da Administração Pública. Uma vez definido tal conceito, são analisados os princípios que norteiam sua atuação - mas somente aqueles que fundamentam os argumentos contra a inserção de cláusula compromissória nos contratos administrativos. Ainda neste capítulo é feita uma abordagem sucinta acerca dos atos administrativos, no qual se incluem os contratos desta natureza. Por fim, destina-se um tópico específico para essa espécie peculiar de negócio jurídico.

Partindo de pontos distintos e distantes - arbitragem e administração pública -, ligados, contudo, pelo interesse coletivo da realização da justiça, chega-se ao núcleo do presente trabalho no último capítulo. A análise da validade do pacto arbitral em um contrato administrativo é feita com base em um caso concreto: o do Museu Guggenheim. Da decisão proferida pelo Tribunal de Justiça do Rio de Janeiro, extraiu-se os fundamentos utilizados para declarar nula a cláusula compromissória inserida no contrato firmado entre a Solomon R. Guggenheim Foundation e o município do Rio de 
Janeiro. A partir dali, buscou-se refutar cada um deles visando à afirmativa da questão supracitada.

O presente trabalho foi elaborado com base em pesquisa bibliográfica, incluindo livros de doutrina, revistas especializadas tanto em arbitragem como em direito público e direito administrativo, além de artigos publicados na internet. Com o intuito de enriquecer esta produção, também foram examinadas decisões dos tribunais nacionais que formam vasta jurisprudência sobre o assunto.

Cabe aqui uma última observação: a análise da possibilidade de contratos administrativos preverem arbitragem ficou restrita à legislação, doutrina e jurisprudência brasileiras. Não foi apreciada a possibilidade do Estado brasileiro se submeter à arbitragem no exterior, questão que envolve inúmeros desdobramentos, incluindo, mas, não se limitando à imunidade de jurisdição. 


\section{Arbitragem}

Caracterizado o conflito de interesses entre pessoas, sejam elas físicas ou jurídicas, são basicamente quatro as opções para a sua solução: quedar-se inerte, buscar a autocomposição da controvérsia, acessar o Poder Judiciário ou recorrer aos meios alternativos de solução de disputas mediação, conciliação e arbitragem.

\subsection{Considerações gerais}

A arbitragem é um meio alternativo de solução de controvérsias, presentes ou futuras, resultante da vontade das partes envolvidas que escolhem os árbitros para serem os juízes da celeuma ou o critério para a designação destes. Reside aí a diferença deste instituto em relação à mediação e à conciliação, pois, nesses as pendências não são resolvidas por terceiros. De mútuo acordo, as partes em uma arbitragem também determinam o processo a ser adotado no julgamento e as regras de direito a serem aplicadas na solução do mérito do conflito. Aos árbitros cabe decidir de forma obrigatória o impasse, mediante a prolação de um laudo arbitral.

Deve-se ressaltar que a arbitragem pode ser de Direito Internacional Público - instituída por tratados internacionais e atinente a questões de soberania entre Estados nacionais - ou de Direito Internacional Privado. O enfoque do presente trabalho, contudo, não inclui aquela. Trata tão somente da arbitragem, inclusive a doméstica, como meio de solução de contendas particulares e seu tratamento no Direito brasileiro.

Se no âmbito interno a arbitragem é considerada como meio alternativo de solução de disputas, o mesmo não pode ser dito quanto a sua utilização no comércio internacional. Em conflitos desta natureza, é o 
método usual de resolução de controvérsias ${ }^{5}$. Diante da não adaptação da justiça estatal às particularidades dos negócios internacionais, a utilização da arbitragem no comércio internacional permite a utilização do direito moldado de uma melhor forma às necessidades dos envolvidos nessa atividade. Desta forma as partes evitam que uma possível controvérsia sobre o negócio contratado seja decidida pelo sistema judiciário de um país estrangeiro, e resulte de leis, regras processuais e praxes forenses mais familiares à parte adversária. Têm, ainda, a liberdade de escolher a língua a ser adotada no procedimento arbitral bem como o local onde o julgamento será proferido. A arbitragem tem o condão de afastar a jurisdição das justiças estatais, tanto do país de uma parte como do da outra.

\subsection{Vantagens que a arbitragem apresenta}

A adoção em larga escala da arbitragem é uma tendência mundial e vem se mantendo há décadas ${ }^{6}$. De fato, a arbitragem apresenta uma série de vantagens aos operadores do comércio internacional, que explicam, inclusive, a preferência por esta via. Primeiramente, a arbitragem possibilita uma solução mais rápida que a via tradicional, do recurso ao Poder Judiciário. Ademais, a investidura como árbitro resulta da confiança depositada em determinado indivíduo pelas partes e faz com que o mesmo desempenhe sua função da melhor forma possível. A arbitragem possibilita, ainda, um julgamento mais especializado, por árbitros que se dedicam ao caso com maior atenção. Um outro fator atraente reside na confidencialidade do procedimento, um dever que se aplica a todos os envolvidos, não só aos árbitros. Acredita-se que isso possibilite, inclusive,

\footnotetext{
${ }^{5}$ LEE, João Bosco. O princípio da confidencialidade na arbitragem comercial internacional. In: MENEZES, Wagner (org.). O direito internacional e o direito brasileiro: homenagem a José Francisco Rezek. Ijuí: Ed. Unijuí, 2004 p. 732

6 As estatísticas da Câmara de Comércio Internacional mostram que no ano de 2006, essa instituição processou 593 pedidos de arbitragem, envolvendo um total de 1.613 partes, domiciliadas em 125 países diferentes. Há diversas outras instituições tais como a Corte Internacional para a Resolução de Disputas sobre Investimentos (ICSID), a Associação Americana de Arbitragem (AAA) etc.
} 
um clima menos litigioso entre as partes uma vez que o mercado sequer toma conhecimento da existência da contenda ${ }^{7}$. Por fim, outra vantagem apontada é a flexibilidade que o referido procedimento proporciona. Esta diz respeito tanto à escolha e aplicação de lei estrangeira ou princípios gerais de Direito para reger o mérito da controvérsia como quanto à escolha e aplicação de lei estrangeira ou regras de câmaras arbitrais para reger o procedimento.

Além disso, os tratados internacionais em vigor que tratam da matéria garantem a circulação das sentenças arbitrais, possibilitando desta forma o seu reconhecimento e sua execução em outros países, além daqueles onde as mesmas foram prolatadas ${ }^{8}$.

Apesar de a arbitragem ser um modo de solução de controvérsias habitual no comércio internacional, durante muito tempo foi vista como uma instituição própria dos países industrializados. Na América Latina, se verificava uma generalizada desconfiança em relação a este instituto 9 . São várias as prováveis causas dessa desconfiança, mas que não serão abordadas aqui por fugirem ao escopo deste trabalho. Fato é que no final dos anos 80, iniciou-se um movimento a favor da arbitragem entre os países latinoamericanos, muitos dos quais ratificaram a Convenção de Nova Iorque sobre o reconhecimento e a execução das sentenças estrangeiras e novas legislações foram promulgadas ${ }^{10}$.

\footnotetext{
${ }^{7}$ TIBURCIO, Carmen, O desenvolvimento da arbitragem no mundo e no Brasil. In: MENEZES, Wagner (org.). O direito internacional e o direito brasileiro: homenagem a José Francisco Rezek. Ijuí: Ed. Unijuí, 2004 p. 751

${ }^{8}$ GAMA E SOUZA JR, Lauro. Arbitragem comercial internacional: estudo comparativo entre o sistema jurídico da província de Québec (Canadá) e o novo direito brasileiro de arbitragem. In: Revista de Direito da Procuradoria Geral do Rio de Janeiro. vol. 50. [S.I.: s.n.]. p. 214

${ }^{9}$ CASELLA, Paul B. (org.) Arbitragem: lei brasileira e praxe internacional. $2^{\mathrm{a}}$ ed. ver. e ampl. São Paulo: LTr, 1999.

${ }^{10}$ Caso da Colômbia e da Bolívia, por exemplo.
} 


\subsection{Arbitragem de direito privado no Brasil}

Depois do fracasso de diversos projetos de lei em função da resistência a esta modalidade extrajudicial de solução de controvérsias, os esforços para a reforma da arbitragem no Brasil resultaram na promulgação da Lei ${ }^{\circ}$ 9.307/96. Publicada no Diário Oficial da União em 24 de setembro de 1996, referida lei entrou em vigor no dia 23 de novembro daquele ano. Inspirada na lei de arbitragem espanhola, na lei-modelo sobre arbitragem comercial internacional adotada pela Comissão das Nações Unidas para o Direito Comercial Internacional (UNCITRAL) e nas regras da Convenção de Nova Iorque, esse diploma legal possui dispositivos sobre a autonomia da vontade das partes, a convenção de arbitragem, o procedimento, o reconhecimento e a execução de sentenças estrangeiras ${ }^{11}$.

Nadia de Araujo $^{12}$ esclarece que foram dois os fatos que contribuíram para que esse instituto alcançasse essa viabilidade operacional: o Supremo Tribunal Federal (STF) ter julgado a homologação de sentença estrangeira em que se pedia a validade de um laudo arbitral seu deferimento acabou com a impugnação da constitucionalidade do instituto - e a edição do Decreto $\mathrm{n}^{\mathrm{o}} 4.311$ de 23 de julho de 2002 que internalizou a Convenção de Nova Iorque. Nesse sentido, conforme ensina Carlos Augusto da Silveira Lobo $^{13}$ foi a adesão à Convenção de Nova Iorque que propiciou a confiança dos parceiros internacionais e a certeza de que as sentenças arbitrais prolatadas no Brasil seriam reconhecidas e executadas nos países que subordinam a aplicação da referida Convenção à reciprocidade.

\footnotetext{
${ }^{11}$ GAMA e SOUZA JR, Lauro. Arbitragem comercial internacional. p. 217

${ }^{12}$ ARAUJO, Nadia de. Direito internacional privado: teoria e prática brasileira. $3^{\mathrm{a}}$ ed. atualizada e ampliada. Rio de Janeiro: Renovar, 2006. p. 461.

${ }^{13}$ LOBO, Carlos Augusto da Silveira. Uma introdução à arbitragem internacional. In: ALMEIDA, Ricardo (coord). Arbitragem interna e internacional: questões de doutrina e da prática. Rio de Janeiro: Renovar, 2003. p. 7.
} 
Foi a partir de então que a arbitragem ganhou novo cenário: lei favorável ao seu desenvolvimento, regida nos moldes de tratados internacionais e leis estrangeiras já existentes sobre a matéria, e principalmente, uma postura bastante favorável por parte do Judiciário brasileiro. Hoje, a justiça estatal encara a arbitragem como uma alternativa viável para solucionar a maior parte das controvérsias entre pessoas físicas e jurídicas de direito privado, adotando na maior parte das situações posição semelhante à do Poder Judiciário de países como a França e a Suíça, onde a arbitragem é praticada desde há muito ${ }^{14}$.

A constatação da inexistência de casos relativos ao Direito do Comércio Internacional nos repertórios de jurisprudências nacionais não significa a ausência de conflitos ou que a parte prejudicada não recorra à Justiça. Tampouco é evidência de que as partes recorrem a Judiciários estrangeiros. A prática demonstra que tal inexistência, no que se refere às contendas de comércio internacional, confirma a predileção pela via arbitral.

\subsubsection{Histórico da arbitragem no país}

A arbitragem de direito privado, contudo, não é novidade entre nós. Foi inicialmente prevista na Constituição Imperial de 1824. Já o Código Comercial de 1850 e o Regulamento $\mathrm{n}^{\circ} 737$ do mesmo ano impunham a obrigatoriedade da via arbitral para a solução de determinados litígios. Essa arbitragem compulsória para controvérsias resultantes de contratos de locação mercantil, que envolvessem matéria societária em geral e liquidação de sociedades ou em casos de naufrágios, avarias e quebras deixou de existir no Brasil com o advento da Lei $\mathrm{n}^{\circ} 1.350$ de 1866 . O Decreto $\mathrm{n}^{\circ} 3.900$ de 1867 regulava o juízo arbitral do comércio e foi o primeiro diploma a disciplinar a cláusula compromissória - embora não

\footnotetext{
${ }^{14}$ TIBURCIO, Carmen. O desenvolvimento da arbitragem no Brasil e no mundo. p. 762
} 
figurasse garantia de instauração do juízo arbitral, o que dependia de compromisso. Posteriormente, a arbitragem veio a ser disciplinada pelo Código Civil de 1916 e, mais tarde, pelos Códigos de Processo Civil de 1939 e de 1973.

Mesmo após a promulgação da Lei de Arbitragem, atento ao desenvolvimento da arbitragem no plano internacional, o Brasil aprovou e ratificou várias convenções sobre a matéria ${ }^{15}$. No âmbito do Mercosul, o Brasil ratificou o Protocolo de Cooperação e Assistência Jurisdicional em Matéria Civil, Comercial, Trabalhista e Administrativista de 1992 (Las Leñas - Decreto $\mathrm{n}^{\circ} 2.067$ de 12 de novembro de 1996), aprovou o Acordo sobre Arbitragem Comercial Internacional do Mercosul de 1998 (Decreto ${ }^{\circ}$ 4.719 de 4 de junho de 2003) e o Acordo sobre Arbitragem Comercial entre o Mercosul, Bolívia e Chile de 1998 (Decreto Legislativo no 483 de 2001). Além dessas e da supracitada Convenção de Nova Iorque, em matéria de Direito Internacional ratificou a Convenção do Panamá de 1975 sobre as cartas rogatórias; a de Montevidéu de 1979 sobre a eficácia extraterritorial das sentenças e laudos arbitrais estrangeiros; a do Panamá de 1975 sobre o regime legal das procurações utilizadas no estrangeiro e a de Montevidéu de 1979 sobre as normas gerais de Direito Internacional Privado. O Brasil encontra-se vinculado também ao Protocolo de Genebra de 1923, relativos às cláusulas de arbitragem. Essa evolução, segundo Lauro Gama e Souza Jr. ${ }^{16}$ "marca a reinserção do Brasil no sistema internacional de Direito privado, e, ao nível da arbitragem, elimina a tradicional resistência do país a sua aceitação".

O âmbito de aplicação da Lei $n^{\circ} 9.307 / 96$ não ficou restrito ao da arbitragem internacional, prevê também o processo arbitral nacional. No entanto, este diploma legal, a exemplo da lei holandesa de 1986, da lei

\footnotetext{
${ }^{15}$ DOLINGER, Jacob e TIBURCIO, Carmen. Arbitragem Comercial Internacional - parte II. Rio de Janeiro: Renovar, 2003. p. 41

${ }^{16}$ GAMA E SOUZA JR, Lauro. Arbitragem comercial internacional. p. 217
} 
inglesa de 1996 e da lei alemã de 1998, não as diferencie e adote um regime uniforme para todas ${ }^{17}$. Fica a cargo do intérprete buscar nas normas de Direito Internacional Privado brasileiras a definição de contrato internacional para, a partir daí, fixar a natureza da arbitragem em causa. Embora, a rigor, não se distingam conceitualmente, é oportuno diferenciálas. Ambas envolvem relação jurídica subjetivamente internacional, o que significa dizer que as partes têm domicílios em países distintos, ou contêm algum elemento objetivo de estraneidade, ou seja, o local de sua constituição, do cumprimento da prestação etc ${ }^{18}$. A lei brasileira não define propriamente arbitragem internacional, trata apenas do que seja uma sentença arbitral estrangeira. Ainda que leis estrangeiras incidam em uma arbitragem, se a sentença arbitral for proferida no Brasil será brasileira. Igualmente, será estrangeira aquela arbitragem cuja sentença tiver sido prolatada em outro país ${ }^{19}$. A partir daí pode-se dizer que a arbitragem comercial internacional seria, portanto, aquela que produz uma sentença conectada a sistemas legais de dois ou mais países: aquele no qual foi proferida e aquele(s) em que deverá ser executada.

\subsubsection{A Lei de Arbitragem}

No Direito brasileiro, o juízo arbitral, objeto da Lei $n^{\circ} 9.307 / 96$, é delineado da seguinte forma: “a) convenção de arbitragem (compromisso entre as partes ou cláusula compromissória inserida em contrato - art. $3^{\circ}$ ); b) limitação aos litígios relativos aos direitos patrimoniais disponíveis (art. $1^{\circ}$ ); c) capacidade das partes (art. $1^{\circ}$ ); d) possibilidade de escolherem as partes as regras de direito material a serem aplicadas na arbitragem, sendo ainda admitido convencionar que esta se realize com base nos princípios gerais de

\footnotetext{
${ }^{17}$ Já na França e em países que adotam a Lei Modelo da UNCITRAL, por exemplo, a arbitragem interna e a internacional são reguladas em dispositivos distintos. Os dispositivos que tratam da arbitragem interna são mais detalhados e restritivos que os referentes à arbitragem internacional.

${ }^{18}$ ARAUJO, Nadia de. Direito internacional privado. p. 465

${ }^{19}$ LOBO, Carlos Augusto da Silveira. Uma introdução à arbitragem internacional. In: ALMEIDA, Ricardo (coord). Arbitragem interna e internacional: questões de doutrina e da prática. Rio de Janeiro: Renovar, 2003. p. 8-9
} 
direito, usos e costumes e nas regras internacionais do comércio (art. $2^{\circ}, \S \S$ $2^{\circ}$ e $3^{\circ}$ ); e) desnecessidade de homologação judicial da sentença arbitral (art. 31); f) atribuição a esta dos mesmos efeitos, entre partes, dos julgados proferidos pelo Poder Judiciário (valendo inclusive como título executivo, se for condenatória - art. 31); g) possibilidade de reconhecimento e execução de sentenças arbitrais produzidas no exterior (art. 34 e seguintes). No entanto, como não são os árbitros investidos do poder jurisdicional estatal, não podem realizar a execução de suas próprias sentenças nem impor medidas coercitivas (art. $22 \S 4^{\circ}$ ).

Como a livre disponibilidade de direitos parece ser passagem obrigatória para se apreciar a arbitrabilidade de um litígio, deve-se refletir sobre os contornos do conceito de direitos disponíveis. Patrícia Level ${ }^{20}$ considera direito disponível aquele "sob o total domínio de seu titular, de tal modo que ele pode fazer tudo em relação a este, principalmente alienar, e mesmo renunciar". A Professora Fauvarque-Cosson ${ }^{21}$ leciona que "se nem os imperativos de polícia, nem os de proteção existem, os direitos patrimoniais, mesmo que não adquiridos, podem ser considerados como disponíveis”. Para Cláudio Vianna de $\operatorname{Lima}^{22}$, disponíveis são aqueles bens "apropriáveis, alienáveis que se encontram no comércio jurídico". João Bosco Lee ${ }^{23}$, por sua vez, não considera a noção de renúncia para definir a livre disponibilidade de direitos no campo da arbitragem. Como exemplo, cita o direito da concorrência que é arbitrável, embora como parte das regras de ordem pública econômica seja irrenunciável e inalienável. Como se vê, a resposta à questão, é decepcionante, pois, como afirma o Professor

\footnotetext{
${ }^{20}$ LEVEL, Patrícia. Apud LEE, João Bosco. O conceito de arbitrabilidade nos países do Mercosul. In: Revista de Direito Bancário, do Mercado de Capitais e da Arbitragem. no 8. São Paulo: Editora Revista dos Tribunais, abr-jun. 2000. p. 350

${ }^{21}$ FAUVARQUE-COSSON, B. Apud LEE, João Bosco. O conceito de arbitrabilidade nos países do Mercosul. p. 350

22 VIANNA DE LIMA, Cláudio. Apud, LEMES, Selma Ferreira. Arbitragem na concessão de serviços públicos - arbitrabilidade objetiva. Confidencialidade ou Publicidade Processual? Disponível em < www.camarb.com.br/areas/subareas_impressao.aspx?SubAreaNo=1> Acesso em 07 set. 2007

${ }^{23}$ LEE, João Bosco. O conceito de arbitrabilidade nos países do Mercosul. p. 351
} 
Charles Jarrosson ${ }^{24}$, "não há uma definição verdadeira do que sejam os direitos disponíveis". Assim sendo, buscaremos identificar quais são os direitos indisponíveis.

Para tanto, tem-se frequentemente recorrido à noção de ordem pública, embora não seja aceita de maneira unânime pela doutrina ${ }^{25}$. Algumas matérias, ditas de ordem pública por revestirem um especial interesse social, não podem ser submetidas à arbitragem. É o caso das matérias relativas ao estado e a capacidade das pessoas (como a dissolução do vínculo matrimonial ou o reconhecimento de paternidade) e ao direito penal (sobretudo no que se refere à aplicação das penas restritivas de liberdade). A ordem pública embora estabeleça o limite da disponibilidade dos direitos, e consequentemente, daquilo que é arbitrável, não é um critério indispensável à definição pretendida. Trata-se de um fator suplementar, da mesma forma que o caráter patrimonial - entendido como a possibilidade de ser quantificado monetariamente - da matéria controversa.

No caso concreto, superada a definição de que a matéria litigiosa se refere a direitos patrimoniais disponíveis, para a instituição da arbitragem é necessária, como mencionado acima, uma convenção privada por meio da qual as partes pactuam submeter a decisão do conflito a um terceiro (árbitro). Tal convenção apresenta-se sob duas formas, verificadas em diferentes momentos da evolução da relação entre as partes: a cláusula compromissória e o compromisso arbitral.

A cláusula compromissória consiste na previsão de que futuros e eventuais litígios envolvendo determinada relação serão resolvidos por meio da arbitragem. É uma avença prévia à existência do próprio conflito, pela qual as partes se comprometem a celebrar o compromisso arbitral e

\footnotetext{
${ }^{24}$ JARROSSON, Charles. Apud LEE, João Bosco. O conceito de arbitrabilidade nos países do Mercosul. p. 351

${ }^{25}$ Ibid. p. 351
} 
instituir o juízo arbitral quando da verificação de alguma divergência em relação ao negócio realizado. Já o compromisso arbitral é ato solene por meio do qual as partes instituem o juízo arbitral para decidir sobre o conflito verificado, definindo os árbitros, seu âmbito de competência, o objeto do litígio, além de outros dados, como o prazo em que deve ser proferido o laudo arbitral e a autorização para julgamento por eqüidade. No atual sistema brasileiro, não há mais distinção quanto aos efeitos da cláusula compromissória e compromisso (art. $3^{\circ}$ da Lei de Arbitragem e art. 267, VII do CPC). Ao pactuarem a cláusula compromissória ou o compromisso arbitral, às partes é facultado optar pela arbitragem de direito ou de eqüidade, escolhendo livremente as regras de direito a serem aplicadas, contanto que não importem em violação à ordem pública ou aos bons costumes.

A arbitragem de eqüidade constitui alternativa ao julgamento de acordo com as regras do direito estrito. As partes autorizam os árbitros a julgar de acordo com a prudência e a consciência, visando o justo e o equânime. Pautam-se nos princípios morais básicos de convivência social. Também é possível que se baseiem nos princípios gerais de direito, nos usos e costumes e na Lex Mercatoria, como são conhecidas as regras internacionais do comércio. Da mesma forma, nada obsta que se solucione o litígio através das regras de direito e dos princípios de eqüidade - embora nesse caso tal aplicação remeta às diversas funções da eqüidade que não serão abordadas aqui, pois é a acepção função substitutiva pura a empregada na arbitragem. É de grande valia, pois não raro a estrita aplicação do direito não garante uma decisão justa. Muitas vezes o magistrado que segue rigorosamente o mandamento do texto legal, ao invés de abrandá-lo em função da especificidade da situação real, pratica injustiça. No entanto, ao autorizar os árbitros a deixar de lado as regras de direito posto para que julgue segundo o que lhes pareça justo no caso 
concreto, as partes sujeitam-se a sérios riscos quanto à previsibilidade jurídica da decisão a ser proferida.

Uma das inovações da Lei de Arbitragem foi a de imprimir força cogente à cláusula arbitral, afastando, obrigatoriamente, a solução judicial do litígio. À luz dos dispositivos da Lei $n^{\circ}$ 9.307/96, tem-se claro que a partir do momento em que, no contexto do instrumento contratual, as partes envolvidas estipulam a cláusula compromissória, está definitivamente imposta como obrigatória a via extrajudicial para a solução de litígios envolvendo o ajuste.

O juízo arbitral não pode ser afastado unilateralmente, de forma que é vedado a qualquer uma das partes contratantes impor seu veto ao procedimento pactuado. Em síntese, na vigência da cláusula compromissória, é permitido ao contratante interessado na resolução do conflito tomar a iniciativa para a instauração da arbitragem. Formalizado o pedido, fica a outra obrigada a aceitá-la sem possibilidade alguma de optar, unilateralmente, pela jurisdição estatal. Nessa linha, a Ministra Ellen Gracie $^{26}$ já afirmou:

Negar possibilidade a que a cláusula compromissória tenha plena validade e que enseje execução especifica importa erigir em privilégio da parte inadimplente a furtar-se à submissão à via expedida de solução da controvérsia, mecanismo este pelo qual optara livremente, quando da lavratura do contrato original em que inserida essa previsão. É dar ao recalcitrante o poder de anulação de condição que - dada a natureza dos interesses envolvidos - pode ter sido consideração básica à formação da avença.

Outro tópico que merece atenção é o da inserção, em um mesmo contrato, da cláusula compromissória e da cláusula de eleição de foro, pois há autores que entendem ser incompatíveis ${ }^{27}$. Em boa técnica, contudo,

\footnotetext{
26 Agravo regimental na sentença estrangeira $n^{\circ}$ 5.206, Rel. Min. Sepúlveda Pertence. DJ 30.04.2004

${ }^{27}$ CARMONA, Carlos Alberto. Considerações sobre a cláusula compromissória e a cláusula de eleição de foro. In: LEMES, Selma Ferreira; CARMONA, Carlos Alberto; MARTINS, Pedro
} 
seria inclusive desejável que o contrato no qual as partes pactuem arbitragem, contivesse, em seguida, uma cláusula de eleição de foro indicando o local para a propositura de eventuais demandas relativas à arbitragem, caso se torne necessário o acesso à justiça estatal. Tais hipóteses são tipicamente de caráter instrutório ou emergencial. A eleição de foro também pode dizer respeito às providências posteriores à arbitragem: execução das sentenças arbitrais ou mesmo sua anulação (arts. 32 e 33 da Lei de Arbitragem).

A convivência entre cláusula compromissória e cláusula de eleição de foro tem ainda outros desdobramentos. Para Carlos Alberto Carmona ${ }^{28}$, "nada impede que a cláusula compromissória abranja apenas algumas questões relativas à relação jurídica que envolve as partes”. Ou seja, as partes podem limitar questões eventuais e futuras à apreciação dos árbitros e retirar deles a competência para decidir sobre algumas matérias determinadas. Nesses casos, devem eleger foro para o debate judicial e a cláusula arbitral deve ser interpretada restritivamente.

Tampouco é incompatível com a cláusula de eleição de foro a cláusula compromissória que aponte instituição arbitral estrangeira para resolver a controvérsia. As partes podem indicar que eventual discórdia seja dirimida por instituições como a Câmara de Comércio Internacional, e escolher algum lugar fora do território nacional para ser a sede da arbitragem e, ainda assim, vincular órgãos jurisdicionais brasileiros para executar a sentença arbitral por eles proferida - desde que homologada pelo Superior Tribunal de Justiça.

Por fim, cabe observar os ensinamentos de Nadia de Araujo ${ }^{29}$ quando afirma que:

Batista (coord.). Arbitragem: estudos em homenagem ao Prof. Guido Fernando da Silva Soares. São Paulo: Atlas, 2007. p. 46

${ }^{28}$ Ibid. p. 43

${ }^{29}$ ARAUJO, Nadia de. Direito internacional privado. p. 475 
entre a edição da Lei $\mathrm{n}^{\circ}$ 9.307/96 e os dias de hoje, a arbitragem teve grande progresso no Brasil, sobretudo no plano doméstico, onde era encarada com grande reticência e como modo alternativo de solução de controvérsias. A arbitragem vem sendo utilizada em litígios comerciais, com a proliferação de institutos arbitrais ligados a câmaras de comércio ou associações comerciais. $\mathrm{O}$ Judiciário tem favorecido os tribunais arbitrais, relevando maturidade na sua relação com o instituto.

Não obstante referido avanço da arbitragem no país, ainda causa polêmica a possibilidade da participação em arbitragens do Estado e entes que integram a Administração Pública. Isto porque referido diploma legal não dispõe acerca da capacidade do Estado brasileiro se submeter à arbitragem. Tal omissão pode ser justificada por pertencer ao direito privado $^{30}$. Assim, faz-se necessário o estudo das normas de direito público sobre o tema, conforme se verá a seguir.

\footnotetext{
${ }^{30}$ MEDEIROS, Suzana Domingues. Arbitragem envolvendo o estado no direito brasileiro. In: Revista de Direito Administrativo, vol. 233 - jun/set. 2003. p. 73
} 


\section{Administração Pública}

O vocábulo administração pública abrange tanto a atividade de planejar, dirigir e comandar como a atividade subordinada de executar. Em ambos os aspectos, verifica-se que há uma relação de hierarquia. Os atos de administração em geral, incluídos ai não só em relação ao direito público, mas também ao privado, limitam-se ao de guarda, conservação e percepção dos frutos advindos dos bens administrados. Não incluem, portanto, os de alienação.

\subsection{Considerações gerais}

$\mathrm{O}$ administrador deve sempre seguir as orientações que the são impostas por uma vontade externa. Vontade essa que pode ser individual ou coletiva, vinculada ao princípio da finalidade: toda atividade administrativa deve ser útil ao interesse que o administrador deve satisfazer. Em se tratando da Administração Pública, a vontade é decorrente da lei que estabelece o fim a ser perseguido pelo administrador. Não há liberdade de opção para que a autoridade administrativa defina a finalidade de determinado ato.

Em sentido subjetivo, pode-se definir Administração Pública como o conjunto de órgãos e de pessoas jurídicas aos quais a lei atribui o exercício da função administrativa do Estado ${ }^{31}$. No Direito positivo brasileiro, a expressão inclui não só a chamada Administração Direta, formada pela União, Estados, Distrito Federal e Municípios, mas também abrange a Indireta, ou seja, as autarquias, empresas públicas e sociedades de economia mista. Também estão abarcadas por este conceito as fundações instituídas

\footnotetext{
${ }^{31}$ DI PIETRO, Maria Sylvia Zanella. Direito Administrativo. $11^{\text {a }}$ ed. São Paulo: Atlas, 1999. p. 62
} 
ou mantidas com recursos públicos e outras pessoas de direito privado sob controle estatal.

\subsection{Princípios da Administração Pública}

O Direito Administrativo é informado por diversos princípios que permitem à Administração Pública e ao Poder Judiciário estabelecer o equilíbrio necessário entre os direitos dos administrados e as prerrogativas da Administração. A Constituição Federal de 1988 menciona expressamente alguns princípios a que se submete a Administração Pública direta, indireta ou fundacional. Para o melhor entendimento acerca da validade da cláusula arbitral em contratos administrativos - tema do capítulo seguinte - o presente abordará, em especial, os princípios da legalidade administrativa, da publicidade, da indisponibilidade do interesse público e da inafastabilidade do controle jurisdicional.

O princípio da legalidade vem inserido no artigo 37 da Constituição Federal. Resulta deste que na relação administrativa, a vontade da Administração Pública é a que decorre da lei. Diferentemente do âmbito das relações particulares em que o princípio aplicável é o da autonomia da vontade, a Administração só pode fazer aquilo que a lei permite, dela não podendo se afastar. Qualquer ação estatal sem o correspondente calço legal, ou que exceda o âmbito demarcado pela lei, é injurídica e fica sujeita à anulação. Disto resulta que a Administração por simples ato administrativo não pode conceder direitos de qualquer espécie, criar obrigações ou impor vedações aos administrados. Se a lei nada dispuser, a Administração não pode agir, exceto em situações de grave perturbação da ordem e guerra. Ante o exposto, pode-se afirmar que seu campo de atuação é mais restrito que o do particular. Nascido com o Estado de Direito, constitui uma das principais garantias de respeito aos direitos individuais, pois ao defini-los, a lei simultaneamente estabelece os limites da atuação administrativa que 
tenha por objeto a restrição ao exercício de tais direitos em benefício da coletividade.

Essa noção clássica da legalidade administrativa como vinculação positiva à lei está superada. A juricidade da ação administrativa hoje não está mais condicionada em sua totalidade à vontade previamente manifestada pelo legislador. Há hipóteses - como, por exemplo, na arbitragem de contratos administrativos - em que a legalidade estrita não pode imperar soberana, em detrimento de outros princípios e valores também constitucionais.

Já o princípio da publicidade, também previsto no artigo 37 da Constituição Federal, consiste no dever da Administração manter plena transparência em seus comportamentos. Deve divulgar amplamente os atos por ela praticados, para conhecimento, controle e início de seus efeitos. Representa a garantia de conhecimento pela população dos atos praticados pelo Poder Público. Ao exigir transparência na conduta do administrador, a Constituição procura inviabilizar o sigilo das escolhas administrativas, que viola o princípio republicano e democrático. Marçal Justen Filho ${ }^{32}$ revela também o caráter educativo da publicidade, pois "desincentiva irregularidades, especialmente em vista da ampliação da possibilidade de repressão a ilícitos e desvios”. Na esfera administrativa, excepcionalmente se admite o sigilo quando este for imprescindível à segurança da sociedade e do Estado. É possível ainda restringir a publicidade quando a defesa da intimidade ou o interesse social o exigirem.

O princípio da indisponibilidade dos interesses públicos significa, nas palavras de Celso Antonio Bandeira de Mello ${ }^{33}$

\footnotetext{
${ }^{32}$ JUSTEN FILHO, Marçal. Curso de direito administrativo. São Paulo: Saraiva, 2005. p. 65

${ }^{33}$ MELlo, Celso Antonio Bandeira de. Curso de direito administrativo. São Paulo: Malheiros, 1995. p. 31-33
} 
sendo interesses qualificados como próprios da coletividade - internos ao setor público - não se encontram à livre disposição de quem quer que seja, por inapropriáveis. $\mathrm{O}$ próprio órgão administrativo que os representa não tem disponibilidade sobre eles, no sentido que lhes incumbe apenas curá-los - o que é também um dever - na estrita conformidade do que dispuser a intentio legis (...) Esta disponibilidade está permanentemente retida nas mãos do Estado (e de outras pessoas políticas, cada qual na sua própria esfera) em sua manifestação legislativa.

Tanto para a doutrina como para a jurisprudência, em se tratando de interesses públicos e direitos a eles associados, mesmo de natureza contratual, estes ficam sujeitos, portanto, a uma presunção de indisponibilidade. Somente uma manifestação legislativa afastando tal presunção geral pode torná-los disponíveis. Fundamento disto reside no paradigma clássico do Direito Administrativo, segundo o qual a supremacia do interesse público sobre o interesse privado fundamenta e legitima todos os privilégios de natureza material e processual em favor da Administração.

Atualmente, contudo, o Direito Administrativo ganha novos contornos com a superação da antinomia entre interesse público e privado, pressuposta pela idéia clássica de supremacia do interesse público. Ambos os interesses estão enraizados na Constituição, o que representa a existência de uma conexão estrutural entre eles. O intérprete do Direito deve, portanto, considerar as especificidades do caso concreto e não reconhecer desde logo uma única e invariável relação de prevalência do interesse público. Uma atitude assim não respeita o princípio da proporcionalidade, cuja observância é imperativa.

Com a ampliação do Estado Democrático de Direito e a contratualização das atividades estatais, a regra da indisponibilidade dos direitos e interesses do Estado, objeto dos contratos administrativos, foi atenuada. Marçal Justen Filho ${ }^{34}$ atesta que:

\footnotetext{
${ }^{34}$ JUSTEN FILHO, Marçal. Curso de direito administrativo. p. 276-277
} 
os poderes públicos deixam de ser exercitados autoritariamente, e a democracia se manifesta como concordância das decisões públicas com os interesses concretos da comunidade.

Nesse contexto a indisponibilidade absoluta se aplica apenas aos interesses públicos que se referem à sociedade como um todo, quais sejam: a promoção e concretização da dignidade da pessoa humana, da justiça, da democracia, do desenvolvimento econômico, da proteção ao meio ambiente etc. Diante dessa categoria, o regime público é indispensável. Há, contudo, uma outra espécie de interesse público, aquele das pessoas jurídicas que administram a coletividade e, como tais, precisam de autorização constitucional genérica e, por vezes, de autorização legal. Esses, secundários, são instrumentos para a materialização daqueles, chamados de primários. Como têm expressão patrimonial e, como podem ser quantificados monetariamente, tornam-se disponíveis, independente do regime.

Por fim, o princípio da inafastablidade do controle jurisdicional é contemplado no art. $5^{\circ}, \mathrm{XXXV}$ da Constituição Federal. Referido dispositivo estabelece que a lei não excluirá da apreciação do Poder Judiciário lesão ou ameaça a direito. É um princípio cujo imperativo destina-se a todos, indistintamente. Em outras palavras, significa que norma alguma pode obstaculizar o direito de ação. O provimento jurisdicional é um direito reflexo ao poder-dever do juiz de dar referida prestação, que decorre da transferência ao Estado da função de dizer o direito para o caso concreto - da atividade de dirimir os litígios decorrentes dos conflitos de interesse.

\subsection{Atos administrativos}

Há diversos critérios para classificar os atos administrativos, importando nesse contexto a classificação quanto às prerrogativas com que 
atua a Administração Pública, caso em que os atos podem ser de império ou de gestão. Aqueles podem ser definidos como os praticados pela administração com todas as prerrogativas e privilégios de autoridade e impostos unilateral e coercitivamente ao particular, independente de autorização judicial. Os atos de gestão, em contrapartida, são aqueles praticados pela Administração em situação de igualdade com os particulares, visando à conservação e o desenvolvimento do patrimônio público bem como a gestão de seus serviços. Referida distinção serve também para definir a competência da jurisdição administrativa - que aprecia os atos de império - , enquanto os atos de gestão ficam a cargo do Poder Judiciário. Atualmente, essa distinção foi substituída por outra: atos administrativos - regidos pelo direito público - e atos de direito privado da Administração. Dá-se o nome de atos administrativos aos primeiros; os últimos, por serem regidos pelo direito privado, são apenas atos da Administração.

Esta classificação é relevante no âmbito dos contratos da Administração. Em sentido amplo, esta expressão é utilizada para abranger todos os contratos celebrados pela Administração, seja sob regime de direito público ou privado. A expressão contrato administrativo, por sua vez, designa tão-somente os ajustes que a Administração, nessa qualidade, celebra com pessoas físicas ou jurídicas, públicas ou privadas, para a consecução de fins públicos, segundo regime de direito público.

Outra dicotomia que importa esclarecer refere-se a serviço público e atividade econômica. No Brasil, o universo das atividades de aproveitamento de bens econômicos para a satisfação de necessidades coletivas comporta duas manifestações diversas: as atividades de serviços públicos e as econômicas em sentido próprio. As atividades econômicas propriamente ditas sujeitam-se ao regime jurídico de direito privado, o qual é aplicado mesmo quando o Estado as desempenha. Estas se subordinam ao 
princípio da livre iniciativa. Os contratos relativos à atividade econômica em sentido estrito - serviços públicos de natureza industrial ou atividade econômica de produção e comercialização de bens, suscetíveis de produzir renda e lucro - envolvem direitos transacionáveis. Marçal Justen Filho ${ }^{35}$ define tais conceitos como "aqueles que envolvem o oferecimento de utilidades materiais necessárias à sobrevivência digna do indivíduo, tais como água tratada, a energia elétrica, as telecomunicações”.

\subsection{Contrato administrativo}

Em matéria de contratos administrativos, a doutrina não é unânime. Maria Sylvia Zanella Di Pietro ${ }^{36}$ aponta para a existência de três correntes. A primeira nega a existência de contrato administrativo. Os adeptos desta, entre os quais figura Oswaldo Aranha Bandeira de Mello, argumentam que o chamado contrato administrativo não observa o princípio da igualdade entre as partes, o da autonomia da vontade e o pacta sunt servanda.

Já para a segunda corrente, adotada entre outros por José Roberto Dromi, todo contrato celebrado pela Administração Pública é contrato administrativo. Não admite a existência de contratos de direito privado nesse âmbito, pois sempre que a Administração é parte em um acordo, o regime jurídico administrativo interfere. Aplica-se sempre o direito público - e não o privado - às matérias de competência, forma, procedimento e finalidade.

A terceira corrente, por sua vez, aceita a existência de contratos administrativos como espécie do gênero contrato, com características próprias, derrogatório e exorbitante do direito comum. Essa é a posição

\footnotetext{
${ }^{35}$ Ibid. p. 499

${ }^{36}$ DI PIETRO, Maria Sylvia Zanella. Direito Administrativo p. 232
} 
adotada pela maioria dos administrativistas brasileiros e que será explorada a seguir.

O contrato administrativo é uma espécie distinta do contrato civil, cujo fundamento reside na autonomia da vontade em sentido próprio. Tratase de um acordo de vontades entre um órgão da Administração Pública, agindo nessa qualidade, e um terceiro (particular ou outra entidade administrativa), para a consecução de objetivos de interesse público. Produz efeitos para pelo menos uma das partes.

Esse ajuste é sempre um ato jurídico bilateral, se forma a partir da declaração de vontade usualmente de duas partes, não é um ato unilateral e impositivo da Administração. Em regra, é formal porque exige forma escrita e requisitos especiais; oneroso, tendo em vista que ambas as partes obrigam-se a uma prestação e auferem vantagens recíprocas (mas como produzir obrigações recíprocas não é de sua essência, pode ser que gere direitos apenas para uma das partes); comutativo, pois deve haver uma equivalência entre a prestação e a contraprestação; e de caráter personalíssimo visto que exige a pessoa do contratado para a sua execução.

O impacto do regime de direito público altera a fisionomia contratual dos contratos administrativos. O que caracteriza o contrato administrativo e o distingue do privado é a participação da Administração na relação bilateral com supremacia de poder para estabelecer as condições iniciais do ajuste. A possibilidade da atuação unilateral da Administração para alterar seu conteúdo ou mesmo rescindir o contrato, e o exercício de prerrogativas que ordinariamente não existem nos contratos entre particulares são os traços típicos e marcantes dessa posição privilegiada ${ }^{37}$.

\footnotetext{
${ }^{37}$ MEIRELLES, Hely Lopes. Licitação e contrato administrativo. $10^{\mathrm{a}}$ ed. atual. São Paulo: Editora Revista dos Tribunais, 1991. p. 182
} 
Para Diogo de Figueiredo Moreira Neto ${ }^{38}$, tais cláusulas exorbitantes podem ser sistematizadas de acordo com as distintas roupagens jurídicas que se apresentam na legislação. A primeira categoria constitui a das cláusulas de executoriedade. Essas são extracontratuais, decorrem da lei e não de imposição contratual. Isto porque também é extracontratual o privilégio da execução prévia. Já o grupo das cláusulas jus variandi possibilitam a alteração unilateral - são a expressão do império da Administração. Além de limitadas pela lei, a doutrina insiste que sejam submetidas a um juízo de razoabilidade. Por fim, as cláusulas de previsão de efeitos sobre terceiros são aquelas que atribuem direito de expropriação, de receber tarifas, de exercer atividades de polícia etc, podendo refletir sobre outros que não os envolvidos na relação contratual. No caso dos contratos administrativos não são criações contratuais, resultam apenas da aplicação das leis.

Tais faculdades, contudo, não são ilimitadas: o interesse econômico do particular deve ser resguardado. A Administração não pode atuar unilateralmente para obter lucros e benefícios para si própria em detrimento do patrimônio do outro contratante. Todo e qualquer exercício das prerrogativas extraordinárias só pode ser tido como legítimo se for instrumento para realizar a função imposta ao Estado de concretizar os direitos fundamentais dos cidadãos. Não se admite, portanto, que a Administração se libere dos deveres assumidos através da faculdade de alteração unilateral. Tampouco são válidas imposições desta natureza quando busca realizar interesses secundários.

Outra característica que reforça a sua natureza administrativa é a exigência de licitação prévia. Outra peculiaridade é o fato a exceção do contrato não cumprido, defesa nos contratos privados, não poder ser, a princípio, invocada pelo contratante contra a Administração. O princípio da

\footnotetext{
${ }^{38}$ MOREIRA NETO, Diogo de Figueiredo. Mutações do direito administrativo. p. 405
} 
continuidade do serviço público impede que o particular deixe de executar o contrato em função de atraso ou omissão estatal, salvo quando tal falta cria um encargo extraordinário e insuportável para a outra parte. Em regra, a exceção é substituída pela indenização dos prejuízos sofridos. A Administração, entretanto, pode invocar essa faculdade em seu favor, caso o particular não cumpra o ajuste.

O fato de a Administração integrar uma relação de negócio com prerrogativa de Poder Público não desnatura o contrato e tampouco lhe retira a natureza consensual. Apenas qualifica o ajuste como contrato público regido por normas próprias de Direito público, visando atender ao interesse público.

O objeto, a finalidade e o interesse público não caracterizam o contrato administrativo. O objeto em regra é o mesmo de um contrato de Direito privado - serviço, obra, alienação, compra e venda, locação etc. A finalidade e o interesse público, por sua vez, estão sempre presentes em qualquer contrato da Administração, como pressupostos de toda atuação estatal. De fato, é inadmissível que a Administração celebre contratos sem finalidade pública ou contra o interesse coletivo. Se isto ocorrer, o ajusto é nulo por desvio de finalidade.

O regime jurídico dos contratos administrativos varia dependendo da situação funcional em que a Administração se encontre, o que permite a diferenciação de três categorias de contratos. Primeiramente se identificam os contratos administrativos propriamente ditos, cujo objeto consiste em prestações realizadas entre particulares e o Estado, sujeitos a um regime de direito público próprio definido, sobretudo, na Lei nº 8.666/93. Em segundo lugar, existem os contratos de delegação de competências administrativas que atribuem a um terceiro o desempenho de funções tipicamente estatais, desencadeando relações jurídicas de direito público perante os 
administrados. Esses são, em especial, os contratos de concessão de serviços públicos. Estão regidos subsidiariamente pela Lei $n^{\circ}$ 8.666/93. Por fim, há aqueles subordinados preponderantemente ao direito privado, em que a participação de ente administrativo não implica mudança significativa do regime jurídico. São os contratos referidos no art. 62 , $\S 3^{\circ}$, I do diploma legal ora citado.

Com a democratização do Estado, os bens e serviços dos particulares deixaram de ser requisitados compulsoriamente pelos governantes e ampliou-se a utilização do contrato administrativo, cuja relevância é cada vez maior. No moderno Direito Administrativo brasileiro, as premissas atuais que orientam a conjugação do interesse estatal com a iniciativa privada demonstram a quebra de antigos paradigmas e, diante dessa realidade, parece ser irreversível e cada vez mais presente o instituto da arbitragem nos contratos administrativos. Este é precisamente o tema que será abordado no próximo capítulo. 


\section{Arbitragem nos contratos administrativos}

Uma vez abordado o tema do contrato administrativo e da arbitragem, volta-se à análise da participação do Estado em arbitragens de direito privado com base em um caso concreto: o do Museu Guggenheim.

\subsection{Caso Guggenheim}

Em 2003, o município do Rio de Janeiro - pessoa jurídica de direito público interno - e a Solomon R. Guggenheim Foundation, pessoa jurídica estrangeira, celebraram um contrato cujo objeto era a instalação do Museu Guggenheim, no píer da Praça Mauá, no centro da cidade. Referida construção era parte de um projeto de recuperação urbanística de importante zona da cidade, objetivando a retomada do desenvolvimento e do progresso local, com estímulo à economia e geração de empregos, além de contribuir para o aprimoramento cultural do município.

Eliomar de Souza Coelho, na qualidade de terceiro interessado, ajuizou uma ação popular em face da cidade do Rio de Janeiro, do prefeito César Epitácio Maia e da referida Fundação visando à nulidade dos contratos celebrados para construção e operação do museu ${ }^{39}$. Dentre os argumentos constava argüia-se pela nulidade da cláusula arbitral.

Como motivo de nulidade da convenção de arbitragem, invocou-se que a arbitragem seria incompatível com o principio da indisponibilidade do interesse público, tido como corolário do principio da legalidade mencionado no capítulo anterior. Sendo indisponíveis os interesses postos

\footnotetext{
${ }^{39}$ TJRJ, Agravo de instrumento $n^{\circ} 07839 / 2003,13^{\text {a }}$ C.C. 29.10 .2003
} 
sob a guarda da Administração - no caso as verbas municipais -, não estaria preenchido o requisito do art. $1^{\circ}$ da Lei de Arbitragem ${ }^{40}$.

Tais razões seduziram o Juízo antes de serem confirmados pelo Tribunal de Justiça do Rio de Janeiro. O Tribunal acrescentou ainda que a Lei de Arbitragem não teria afastado a vedação de seu uso nos contratos administrativos regulamentados pela Lei $n^{\circ} 8.666 / 93$, especificamente o seu art. 55, cujo texto outorga competência exclusiva ao Juízo do foro da Administração.

A redação final da ementa do acórdão, contudo, sequer aprecia tal incompatibilidade. Argumenta que a arbitragem, por ser confidencial e sigilosa, seria incompatível com o principio da publicidade a que se submete a Administração Pública ${ }^{41}$.

Como se vê, essa da questão da participação da administração pública em arbitragens é um tema bastante polêmico, tanto no Brasil como no exterior. Essa discussão envolve uma significativa produção doutrinaria e já há diversos precedentes jurisprudenciais ${ }^{42}$. Tem acarretado também debate no âmbito administrativo. Diversas decisões foram proferidas pelo Tribunal de Contas da União $^{43}$ analisando a possibilidade de entes da Administração Pública pactuarem arbitragem. Embora não sejam uniformes, em regra tais decisões são no sentido de não permitir a arbitragem sem lei que expressamente a autorize. Na esfera judicial

\footnotetext{
${ }^{40}$ FIGUEIREDO, Lucia Valle. Curso de direito administrativo. $6^{\mathrm{a}}$ ed. São Paulo: Malheiros, 2003. p. 106

41 VALENÇA FILHO, Clávio. Validade e eficácia da convenção de arbitragem em contratos administrativos: a ótica judiciária. In: Lemes, Selma Ferreira; Carmona, Carlos Alberto; Martins, Pedro Batista. Arbitragem: estudos em homenagem ao Professor Guido Fernando da Silva Soares. São Paulo: Atlas, 2007. p. 441

42 STF, AI 52. 191, Pleno, Rel. Min. Bilac Pinto, RTJ 68/382 (caso "Lage”); TJDF (Conselho Especial, MS 1998.002.003066-9 Rel ${ }^{\mathrm{a}} \mathrm{Des}^{\mathrm{a}}$ Nancy Andrighi, J. 18.05. 1999, DJ 18.08.1999; TAPR, AC 247.646-0, 7ª C. Cível, Rel. Juiz Lauro Laertes de Oliveira, J. 11.02.2004 (caso "Compagás").

${ }^{43}$ Decisões mais recentes sobre o tema incluem o Acórdão no 1.271, Plenário, Rel. Min. Marcos Bemquerer Costa, J. 24.08.2005 e Acórdão n n37/2006, 2 ${ }^{\text {a }}$ C. Rel. Min. Walton Alencar Rodrigues, J. 14.03.2006
} 
verifica-se um aumento do número de decisões favoráveis ao pacto arbitral em contratos administrativos. Não se pode afirmar, portanto, que a questão já seja pacifica - como evidencia a ação popular sob comento.

Além dos argumentos utilizados no referido acórdão, há outras objeções formuladas acerca do cabimento da arbitragem envolvendo a Administração que sequer foram invocadas, mas que também serão analisadas neste capítulo. São elas:

i) o princípio da legalidade exige a existência de autorização legal específica para que seja possível o pacto arbitral por ente da Administração ${ }^{44}$; e

ii) o princípio da inafastabilidade do controle jurisdicional, que impediria o caráter definitivo da sentença $\operatorname{arbitral}^{45}$.

\subsubsection{Arbitrabilidade}

Pretende-se ao longo deste capítulo refutar os óbices supracitados. Primeiramente, é preciso esclarecer que essa questão da inclusão de pacto arbitral em contratos administrativos pode ser abordada, dentre outras, pela ótica do direito arbitral. Nesse caso, é preciso que se distinga a arbitrabilidade subjetiva da objetiva, conceitos que estão presentes no artigo $1^{\circ}$ da Lei de Arbitragem.

Para definir precisamente o significado de arbitrabilidade, vale transcrever as lições de Jacob Dolinger e Carmen Tibúrcio ${ }^{46}$ :

\footnotetext{
Mesmo se partindo da premissa que a jurisdição - aplicação da lei ao caso concreto - é uma das funções do Estado, admite-se que as partes possam decidir submeter a solução de seus litígios à arbitragem ao invés de à jurisdição estatal. $\mathrm{O}$ Estado conserva, todavia, o poder de impedir que determinadas questões sejam dirimidas pela via de arbitragem, resultando no estabelecimento da regra da

${ }^{44}$ BINENBOJM, Gustavo. Temas de direito administrativo e constitucional. p. 138

${ }^{45}$ Ibid. p. 138

${ }^{46}$ DOLINGER, Jacob; TIBURCIO, Carmen. Direito internacional privado. p. _-
} 
competência exclusiva da jurisdição estatal no que se refere à determinadas controvérsias. Nesse caso, diz-se que o litígio não é passível de ser resolvido por arbitragem, ou melhor, não é arbitrável. Dessa forma, a arbitralidade é uma condição da validade da convenção arbitral e consequentemente da competência dos árbitros.

A arbitrabilidade subjetiva se refere à capacidade do sujeito incluir no contrato em que seja parte uma cláusula arbitral. Podem valer-se da arbitragem as pessoas capazes. É o que resulta da leitura do art. $1^{\circ}$ da Lei de Arbitragem:

Art. $1^{\circ}$ - As pessoas capazes de contratar poderão valer-se da arbitragem para dirimir litígios relativos a direitos patrimoniais disponíveis.

Nesse mesmo sentido, dispõe o art. 851 do Código Civil:

Art. 851 - É admitido o compromisso, judicial ou extrajudicial, para resolver litígios entre pessoas que podem contratar.

Em regra, a capacidade civil no Brasil torna-se plena aos 18 anos $^{47}$. Salvo as demais hipóteses de incapacidade previstas no ordenamento, qualquer pessoa maior de 18 anos pode submeter à arbitragem litígios que versem sobre direitos disponíveis. Note-se que "capazes de contratar" não significa apenas os capazes. Não há impedimentos para que os incapazes convencionem cláusula ou compromisso arbitral, desde que devidamente assistidos ou representados na forma da lei. Assim, nos casos em que for permitido ao incapaz contratar, poderá também celebrar convenção de arbitragem (desde que a lei brasileira seja a aplicável) ${ }^{48}$.Também podem pactuar a arbitragem as pessoas jurídicas e entes despersonalizados (como, por exemplo, espólio, condomínio e massa falida).

A arbitrabilidade objetiva, por sua vez, diz respeito à matéria objeto do litígio poder ser validamente submetida à apreciação dos árbitros. No ordenamento pátrio, sempre esteve restrita às questões passíveis de

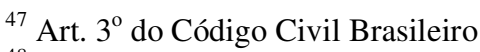

${ }^{48}$ VALLE, Martim Della. Considerações sobre os pressupostos processuais em arbitragem. In: Revista Brasileira de Arbitragem. v.3, n.12 out/dez 2006. Curitiba: Comitê Brasileiro de Arbitragem p. 20 
transação, ou seja, relativas a direitos patrimoniais disponíveis. No tocante aos direitos indisponíveis, o art. 25 da Lei de Arbitragem determina:

Art. 25 - Sobrevindo no curso da arbitragem controvérsia acerca de direitos indisponíveis e verificando-se que de sua existência, ou não, dependerá o julgamento, o árbitro ou o tribunal remeterá as partes à autoridade competente do Poder Judiciário, suspendendo o procedimento arbitral.

De acordo com o art. 852 do Código Civil não é permitido o pacto arbitral que verse sobre questões de estado, de direito pessoal, de família e de outras que não tenham caráter estritamente patrimonial. O dispositivo seguinte, art. 853, faz expressa remissão à lei especial, qual seja, à Lei de Arbitragem. Assim, deve-se aplicar o seu art. $1^{\circ}$ com as restrições enumeradas no art. 852 do Código Civil $^{49}$.

No que se refere à arbitrabilidade objetiva, Diogo de Figueiredo Moreira Neto parece espancar qualquer dúvida ao deixar claro que o Estado ora age com ius imperium ora com ius gestionis ${ }^{50}$. Há dois critérios para diferenciá-los. Pelo da finalidade, se aquela a qual se destina o ato for inerentemente pública é considerado ato de império, quando for privada, tal ato passa a ser considerado como de gestão. Já pelo segundo critério, o da natureza do ato, se o ato puder ser praticado, com a mesma ou outra finalidade, por um particular em suas relações privadas é ato de gestão; se não puder é ato de império. A jurisprudência brasileira parece se firmar de acordo com este segundo critério.

A atuação estatal na figura do ius imperium é aquela que envolve os interesses administrativos originários, que nas palavras de Celso Antonio Bandeira de Mello são aqueles "que a lei aponta como sendo o interesse da coletividade: da observância da ordem jurídica estabelecida a titulo de bem

\footnotetext{
${ }^{49}$ MEDEIROS, Suzana Domingues. Arbitragem envolvendo o estado no direito brasileiro. p. 73

${ }^{50}$ MOREIRA NETO, Diogo de Figueiredo. Apud. LEMES, Selma Ferreira __ In: Anais das palestras proferidas em 2004 na Secretaria Pro Tempore do Conselho de Câmaras de Comércio do Mercosul. Rio de Janeiro: Confederação Nacional do Comércio, 2004.
} 
curar o interesse de todos". Isto significa dizer que se trata de uma questão de Estado, envolvendo direitos indisponíveis e como tal, não sujeitos à arbitragem. No entanto, em se tratando de questões que envolvam o interesse público derivado, do ius gestionis, estas podem ser submetidas à arbitragem.

\subsubsection{Interesse coletivo e interesse da Administração Pública}

No tocante à indisponibilidade do interesse público, não se deve confundir interesse coletivo com o mero interesse do aparato estatal. Nem tudo o que se põe sobre a cura da Administração é indisponível, como o é a realização dos direitos fundamentais. Essa é a doutrina de Caio Tácito ${ }^{51}$.:

Sempre que puder contratar - o que importa em existência de disponibilidade atinente a interesses e direitos patrimoniais -, poderá a Administração, direta ou indireta, convencionar cláusula de arbitragem, sem que isso importe disposição do interesse público, mas, muito ao contrário, um método para satisfazê-lo de modo mais célere, mais técnico, com custos menores e, sobretudo, com a vantagem da consensualidade.

Nesse mesmo sentido, Eros Roberto $\mathrm{Grau}^{52}$ esclarece que:

Assim, é evidente que, quando se afirma que a arbitragem se preste a dirimir litígios relativos a direitos patrimoniais disponíveis, isto não significa não possa a Administração socorrer-se dessa via visando ao mesmo fim. Pois não há qualquer correlação entre a disponibilidade ou indisponibilidade de direitos patrimoniais e a disponibilidade ou indisponibilidade do interesse público.

[...]

A Administração, para a realização do interesse público, pratica atos da mais variada ordem, dispondo de determinados direitos patrimoniais, ainda que não possa fazê-lo em relação a outros deles. Por exemplo, não pode dispor dos direitos patrimoniais que detém sobre os bens públicos de uso comum.

Há, portanto, uma grande distância entre a premissa da indisponibilidade dos direitos fundamentais - cuja proteção cabe ao Estado , e a conclusão de que tudo que se relaciona com a Administração configure objeto de direitos indisponíveis e, como tais, não dotados de arbitrabilidade.

\footnotetext{
${ }^{51}$ Temas de Direito Público. v.3. Rio de Janeiro: Renovar, 2002. p. 83-88

${ }^{52}$ Arbitragem e contrato administrativo. Revista Trimestral de Direito Público. n. 32, p. 20
} 
Há direitos patrimoniais cuja disponibilidade é instrumental para as atividades de entes estatais, sejam eles integrantes da Administração direta ou indireta. Se lhe é dado transigir tendo tais direitos por objeto, não há porque se considerar que os mesmos não sejam disponíveis. É este o caso, por exemplo, da possibilidade de pacto arbitral sobre o reequilíbrio econômico-financeiro de um contrato administrativo ou o pagamento de uma indenização por responsabilidade civil. Os contratos administrativos que versem sobre serviços públicos econômicos ou à atividade econômica de produção ou comercialização de bens envolvem direitos passíveis de discussão em arbitragem.

O ponto central para a compreensão deste tema está no conceito de indisponibilidade. No contexto da revisão desta idéia, tem-se que disponível não é apenas o que pode ser objeto de contratação ou transação, com a transferência do direito a outrem, mas é aquilo em relação a que a Administração pode reconhecer que não tem razão ${ }^{53}$. Isto se aplica igualmente, independente da natureza da atuação da Administração, ainda que envolva a Administração direta ou atos de autoridade da administração. Importa determinar se o interesse da Administração é disponível e se esse interesse pode ser representado pecuniariamente. Estando presentes essas condições, cabível será a arbitragem.

Importa ressaltar que a submissão pelo Estado de uma lide à arbitragem não significa que este está transigindo ou dispondo de um interesse ou direito seu. A pactuação de cláusula compromissória não se caracteriza como típico ato de disposição. A lide será decidida de acordo com a lei aplicável, devendo o árbitro aplicar, quando for o caso, inclusive, regras de ordem pública ou de aplicabilidade imperativa. Em muitos casos,

${ }^{53}$ TALAMINI, Eduardo. apud PEREIRA, César A. Guimarães. Arbitragem e a administração pública - comentários ao acórdão do STJ no REsp 612. 439/RS ("Caso AES Uruguaiana”). Revista Brasileira de Arbitragem. v. 12. out/dez 2006. Curitiba: Comitê Brasileiro de Arbitragem. P. 113 
a arbitragem pode se apresentar como a melhor forma de resguardar o patrimônio público e promover o interesse público ${ }^{54}$.

No caso do Guggenheim, contudo, o Tribunal de Justiça do Rio de Janeiro sequer se deu o trabalho de indagar se o interesse público envolvido era do tipo primário ou se, ao contrário, se tratava de mero interesse da Administração.

\subsubsection{Confidencialidade e princípio da publicidade}

As objeções não param por aí. A princípio, o caráter sigiloso da arbitragem se contrapõe, nesses casos, ao dever de publicidade que rege todos os atos públicos. Uma arbitragem secreta, contudo, por si só não é suficiente para afastar a convenção arbitral. Isto porque, ainda que a maioria dos procedimentos arbitrais seja confidencial, não há qualquer dever legal que imponha isto. Como já mencionado, o sigilo não é mais um requisito essencial da arbitragem como fora outrora. João Bosco Lee ${ }^{55}$ esclarece que:

a expectativa das partes em ter uma arbitragem resguardada pela confidencialidade dependerá das regras aplicadas ao procedimento arbitral, seja o regulamento de uma instituição arbitral ou a lei de um país que admita o sigilo como princípio fundamental da arbitragem e, principalmente, da vontade das partes que podem estipular, por via contratual, a confidencialidade da arbitragem.

A contrário senso se extrai que, como a confidencialidade não se impõe naturalmente às partes envolvidas, em regra, nada as impede de divulgar questões pertinentes à arbitragem. De fato, o art. $13 \S 6^{\circ}$ da Lei de Arbitragem - o único dispositivo que trata do tema - refere-se à obrigação de sigilo imposta tão somente ao árbitro.

\footnotetext{
${ }^{54}$ BINENBOJM, Gustavo. Temas de direito administrativo e constitucional. p. 139

${ }^{55}$ LEE, João Bosco. O princípio da confidencialidade na arbitragem comercial internacional. In: MENEZES, Wagner (org). O direito internacional e o direito brasileiro: homenagem a José Francisco Rezek. Ijuí: Ed. Unijuí, 2004. p. 740
} 
Existem, contudo, aspectos da arbitragem que razoavelmente devem ser preservados da divulgação pública. Esses dizem respeito, por exemplo, às informações divulgadas no curso do procedimento arbitral sobre segredos de comércio, tecnologia, procedimentos de produção, conhecimentos especializados e know-how de propriedade dos contratantes.

Dessa forma, conclui-se que o Tribunal de Justiça do Rio de Janeiro errou ao declarar nula a convenção de arbitragem. Deveria ter remetido as partes ao juízo arbitral para que submetessem à instância arbitral não sigilosa.

\subsubsection{Foro legal exclusivo e instância arbitral}

Nas palavras de Clávio Valença Filho ${ }^{56}$, o judiciário "reticente" comumente invoca o art. $55 \S 2^{\circ}$ da Lei 8.666 para invalidar um pacto arbitral em contrato administrativo. Esse dispositivo impõe o foro legal exclusivo, o que pode provocar disfunções no funcionamento do procedimento arbitral - da mesma forma que a cláusula de eleição de foro, abordada no capítulo específico sobre arbitragem. Isso não quer dizer, contudo, que o pacto arbitral seja inválido ou incompatível com o foro legal.

Não se pode deduzir do referido dispositivo legal que a Administração só esteja autorizada a resolver questões contratuais em juízo e no foro de sua sede. A Administração não está impedida de transigir, de resolver extrajudicialmente as suas questões. Nesse sentido, Marcos Juruena e Diogo de Figueiredo ${ }^{57}$ afirmam:

\footnotetext{
56 VALENÇA FILHO, Clávio. Validade e eficácia da convenção de arbitragem em contratos administrativos: a ótica judiciária. In: LEMES, Selma Ferreira; CARMONA, Carlos Alberto; MARTINS, Pedro Batista (coord.). Arbitragem: estudos em homenagem ao Prof. Guido Fernando da Silva Soares. São Paulo: Atlas, 2007. p.439

${ }^{57}$ Revista de Direito Administrativo. vol. 236, p. 216-217
} 
dentre as formalidades de direito público cite-se a regra por força da qual os contratos da administração devem conter cláusula que estabeleça o foro da administração como competente para apreciar controvérsias, formalidade essa que não pode e não deve ser entendida como uma obrigatoriedade substantiva de que se discuta toda e qualquer questão em juízo e não só porque não se confundem as distintas obrigações em sua natureza, como porque tal confusão conduziria a um absurdo de se impedir qualquer negociação amigável. Portanto, o que faz sentido dessumir do dispositivo do art. $55, \S 2^{\circ}$, é que, em sendo inevitável, as partes podem ir ao Judiciário, indicando para tanto o foro, mas não sem que se lhes permita estabelecer mecanismo de solução de controvérsias.

Como já visto anteriormente, servem a propósitos distintos e não são mecanismos reciprocamente excludentes. No contexto da arbitragem, Lauro Gama e Souza Jr." afirma que "ambas as cláusulas podem e devem coexistir". Inclusive porque há medidas que os árbitros não podem tomar, pois lhes falta o poder de coerção e, portanto, precisam recorrer às autoridades judiciárias estatais para efetivá-las. É o caso, por exemplo, das cautelares incidentais, de condução forçada de testemunhas etc.

Assim, é útil que o contrato preveja um foro de eleição que coincida com o local da arbitragem. Em um contrato administrativo, entretanto, há uma peculiaridade que afasta tal possibilidade de escolha. Como um dos contratantes é a Administração Pública, deve-se atentar para o disposto no art. 55, $\S 2^{\circ}$ da Lei $\mathrm{n}^{\circ} 8.666 / 93$ : o foro competente será necessariamente o da sede da Administração. Não há de se falar, portanto, na eleição de foro diverso.

No caso concreto ora comentado, o contrato deveria, por imposição legal, determinar o foro da cidade do Rio de Janeiro como o competente para apreciar as questões relativas ao negócio objeto do ajuste.

\footnotetext{
${ }^{58}$ GAMA e SOUZA JR, Lauro. Sinal verde para a arbitragem nas parcerias público-privadas (a construção de um novo paradigma para os contratos entre o Estado e o investidor privado). In: Revista Brasileira de Arbitragem. vol. 8, out-dez 2005. p. 35
} 


\subsubsection{Ausência de autorização legislativa específica}

Outro empecilho à arbitragem envolvendo o Poder Público estaria na ausência de autorização legislativa específica ${ }^{59}$. Referida alegação, contudo, não deve prosperar. Não contendo a previsão do art. $1^{\circ}$ da Lei de Arbitragem excludente alguma quanto aos entes estatais ou de contratos regidos pelo Direito Público, deve ser tida como autorização legislativa suficiente para a submissão de entes do Poder Público - diretos ou indiretos - ao juízo arbitral ${ }^{60}$. Ademais, há muito já foi abandonada a idéia do princípio da legalidade administrativa como vinculação positiva à lei, ou seja, de que toda atividade administrativa deva estar prévia e inteiramente prevista na lei.

Há inúmeros campos em que se reconhece à Administração uma série de poderes implícitos ao dever do bem administrar ${ }^{61}$. A pactuação de arbitragem é um dentre eles. Pressuposto da execução de tarefas públicas através da contratação de particulares é o reconhecimento de um conjunto de poderes à Administração como condição para a otimização do gasto de recursos e alcance dos fins perseguidos. Resulta disso que o poder de pactuar compromisso arbitral é implícito ao poder de contratar, restando atendida a legalidade quando a solução arbitral for aquela que realiza de forma mais eficiente, o dever de bem administrar.

Poderia argumentar-se, ainda, que a validade das convenções de arbitragens em contratos administrativos deriva diretamente da natureza jurisdicional da arbitragem, sendo para tanto, desnecessária qualquer forma

\footnotetext{
${ }^{59}$ A título exemplificativo veja-se do TCU, o Acórdão 536/2006, J. 14.03.2006, DOU 17.03.2006 e a Decisão 286/1993 do Plenário.

${ }^{60}$ PEREIRA, César A. Guimarães. Arbitragem e a administração pública - comentários ao acórdão do STJ no REsp 612. 439/RS ("Caso AES Uruguaiana"). In: Revista Brasileira de Arbitragem. v. 12. out/dez 2006. Curitiba: Comitê Brasileiro de Arbitragem. p. 119

${ }^{61}$ BINENBOJM, Gustavo. Temas de direito administrativo e constitucional. p. 139
} 
de autorização legislativa ${ }^{62}$. O reconhecimento desta natureza híbrida do instituto é fundamental, pois afasta o preconceito daqueles que não admitem jurisdição sem que o Estado esteja presente. Ao submeter determinada controvérsia à arbitragem, as partes atribuem ao árbitro os mesmos poderes jurisdicionais que subtraem ao poder estatal (embora este não fique impossibilitado de manifestar-se sobre a validade do ato). Nesse sentido dispõe o art. 18 da Lei de Arbitragem: “o árbitro é juiz de fato e de direito".

No tocante ao princípio da legalidade e seus desdobramentos, cabe aqui uma última observação. Em se tratando de contratos administrativos, não se pode vislumbrar a possibilidade da solução dos conflitos pelo critério da equidade, mencionado anteriormente. Trata-se de uma simples faculdade que pode ou não existir nas arbitragens envolvendo exclusivamente particulares $^{63}$, mas que não se coaduna com a observância pela Administração Pública do princípio da legalidade. Embora o princípio da legalidade administrativa não signifique a vinculação absoluta à lei positiva, daí não resulta que o ente estatal possa agir sem que observe o direito. Desta forma, a arbitragem envolvendo contratos dessa natureza deve ser rigorosamente de direito ${ }^{64}$.

\subsubsection{Inafastabilidade da jurisdição estatal}

Outro argumento que não deve proceder é o da violação ao princípio da inafastabilidade da jurisdição com o intuito de invalidar o pacto arbitral em contrato com a Administração. A um, Geraldo Brindeiro ${ }^{65}$ destaca:

\footnotetext{
${ }^{62}$ VALENÇA FILHO, Clávio. Arbitragem e contratos administrativos. In: Revista de Direito Bancário, do Mercado de Capitais e da Arbitragem. n ${ }^{\circ}$ 8. São Paulo: Ed. Revista dos Tribunais, abr./jul./2000. p. 369

${ }^{63}$ DALLARI, Adilson Abreu. Arbitragem na concessão de serviço público. p. 67

${ }^{64}$ GAMA e SOUZA JR, Lauro. Sinal verde para a arbitragem nas parcerias público-privadas. p. 37

${ }^{65}$ BRINDEIRO, Geraldo. Apud, ALVES, André Camerlingo. A constitucionalidade da lei de arbitragem: jurisprudência comentada. In: Repertório de Jurisprudência IOB. Vol. III, n ${ }^{\circ}$ 17- set. 2004. p. 500
} 
[...] o que o princípio da inafastabilidade do controle jurisdicional estabelece é que a lei não exclui da apreciação do Poder Judiciário lesão ou ameaça a Direito. Não estabelece que as partes interessadas não excluirão da apreciação judicial suas questões ou conflitos. Não determina que os interessados devem sempre levar ao Judiciário suas demandas. Se se admite como lícita a transação relativamente a direitos substanciais objeto da lide, não se pode considerar violência à Constituição abdicar ao direito instrumental de ação através da cláusula compromissória. E, em se tratando de direitos patrimoniais disponíveis, não somente é licito e constitucional, mas também é recomendável aos interessados - diante do acúmulo de processos e do formalismo excessivo que têm gerado a lentidão das demandas judiciais - abdicarem do direito ou do poder de ação e buscarem a composição do conflito por meio de sentença arbitral cujos efeitos sejam idênticos àquele das decisões prolatadas pelo Poder Judiciário.

A dois, porque (i) o Supremo Tribunal Federal já se manifestou positivamente quanto à constitucionalidade da $\operatorname{arbitragem~}^{66}$ e (ii) a opção por esse meio alternativo de solução de controvérsias decorre da disponibilidade dos recursos envolvidos no contrato administrativo, assim qualquer alegação de violação da garantia constitucional supracitada perde sentido. Gustavo Binenbojm ${ }^{67}$ resume com propriedade:

ora, permitida a disponibilidade dos recursos públicos mediante contratação administrativa, segue daí que a Administração poderá também convencionar a forma pela qual os litígios decorrentes do contrato serão dirimidos. O acessório (cláusula compromissória) segue a sorte do principal (disponibilidade dos interesses envolvidos no contrato).

Ressalta-se que a adoção da arbitragem não se choca com a regra constitucionalmente estabelecida no art. $5^{\circ}, \mathrm{XXXV}$. Da leitura dos arts. $32 \mathrm{e}$ 33 da Lei de Arbitragem resulta que é possível invocar o Poder Judiciário contra eventuais desvios no decorrer do procedimento arbitral de forma a proteger os interesses patrimoniais do Estado. Com efeito, o art. 1.046 do Código Civil e o art. 1.101 do Código de Processo Civil deixam o caminho ao Poder Judiciário permanentemente aberto para qualquer das partes caso ocorra qualquer nulidade no curso do procedimento arbitral. Tal possibilidade se aplica principalmente nos casos em que um dos contratantes for um ente da Administração Pública, em que sempre estão presentes interesses públicos, em menor ou maior escala.

\footnotetext{
${ }^{66}$ Sentença Estrangeira no 5.206-7, Rel. Min. Sepúlveda Pertence, j. 12.12.2001

${ }^{67}$ Op. cit. p. 141
} 
O caso da ação popular sob comento ilustra que, em se tratando de possível irregularidade na arbitragem envolvendo um contrato administrativo, o recurso ao Judiciário se estende também a terceiros que se julguem prejudicados.

Não obstante o exposto acima, é oportuno desconstruir o mito de que uma sentença deve por fim ao processo, o que invalidaria a sentença parcial. No âmbito do direito arbitral, a idéia da unidade da sentença deve ser mitigada. É fundamental que seja encarada de forma mais flexível e, assim, condizente com este instituto - calcado na autonomia da vontade e no pressuposto da celeridade da prestação e, ainda, cuja decisão não comporta recurso. Aliás, nesse particular, confira-se Pedro Batista Martins $^{68}$ :

a ausência de agravo, apelação e recurso, creio eu, ajuda a afastar o pretendido malefício da cisão do julgamento que é o de se criar situações incompatíveis com a ordem processual e sua dinâmica normal.

Em regra, a decisão do árbitro em uma arbitragem não é passível de recurso. Isto minimiza a possibilidade de inconsistências que poderiam resultar de decisões em outras instâncias. O pronunciamento do árbitro sobre determinada matéria põe fim a uma pretensão de cunho material de forma definitiva. Estará esta, portanto, apta a transitar em julgado.

Considerando que a demanda contempla pedidos distintos e independentes, nada impede que o árbitro decida um ou alguns deles se já madura a questão. A sentença será definitiva - nos termos da processualística civil -, contudo, parcial até que se julgue a última pretensão, por questões meramente formais e instrumentais. Feito isto, a decisão do árbitro é tida como definitiva sob a ótica jurisdicional - tal como

\footnotetext{
${ }^{68}$ MARTINS, Pedro Batista. A arbitragem e o mito da sentença parcial. In: LEMES, Selma Ferreira; CARMONA, Carlos Alberto; MARTINS, Pedro Batista (coord.). Arbitragem: estudos em homenagem ao Prof. Guido Fernando da Silva Soares. São Paulo: Atlas, 2007. p. 273
} 
as parciais - e, do ponto de vista formal, como final posto que põe termo à contenda.

Como a forma não suplante a substância do ato, a sentença parcial não deixa de alcançar a finalidade social a que se presta: atender o direito material lesado ou ameaçado. Atende também aos princípios da moralidade e da eficiência, que norteiam os atos da Administração Pública, sobretudo aqueles que envolvem a realização da justiça como pressuposto fundamental da paz social. Da mesma forma, atende ao princípio da celeridade e da economia processual.

Por fim, ressalta-se que a eficiência anda na contramão da lentidão, do descaso, da negligência e da omissão, características essas que se verifica com freqüência maior que a desejável e admissível na Administração Pública brasileira. É sob esse viés que deve ser encarada a virtude da sentença parcial: instrumento precioso para a concretização da justiça que não contraria o direito positivo. Nas palavras de Clávio Valença Filho $^{69}$,

não contraria a ordem pública - por não chocar os sentimentos médios de justiça vigentes em nossa população - a prolação de sentença arbitral que não decida totalmente a questão.

Nesse ramo, há vários regulamentos de Câmaras de Arbitragem, inclusive nacionais, que autorizam o árbitro a se pronunciar parcial e definitivamente, sobre questões de mérito.

Essa transformação, verificada mais recentemente também no processo civil com as modificações trazidas pela Lei $\mathrm{n}^{\mathrm{o}} 11.232 / 05^{70}$,

\footnotetext{
69 VALENÇA FILHO, Clávio. Tutela judicial de urgência e a lide objeto de convenção de arbitragem. In: Revista brasileira de arbitragem. vol. 7. [S.I]: IOB, jul./set. 2005, p. 20

${ }^{70} \mathrm{O}$ art. $162, \S 1^{\circ}$ do Código de Processo Civil brasileiro prevê: "Sentença é o ato do juiz que implica alguma das situações previstas nos arts. 267 e 269 desta Lei”. Da mesma forma referida lei alterou o caput desses artigos: "Art. 267 - Extingue-se o processo, sem resolução do mérito [...]" e "Art. 269 - Haverá resolução de mérito [...]". Da leitura do inciso I do art. 269 resulta que o sistema jurídico tenha superado o mito da sentença parcial passando a admiti-la uma vez que
} 
representa enorme avanço no campo da efetividade processual. Isto porque, a aplicação do princípio da unidade da sentença sem qualquer flexibilidade obstrui a justiça e a máxima eficácia normativa dos ditames constitucionais, o que em última análise atenta contra os direitos fundamentais do indivíduo $^{71}$.

\subsubsection{A boa-fé e a vedação do venire contra factum proprium}

Um último ponto não incluído nas cogitações do acórdão comentado porque alheio ao objeto do recurso, mas não menos importante, refere-se à boa-fé.

Internacionalmente, é pacífico que não pode um Estado alegar a existência de disposições restritivas do seu próprio direito para fugir aos efeitos de uma cláusula compromissória ou um compromisso arbitral livremente estipulado. Esse mesmo raciocínio deve ser adotado internamente no país, com base no art. 37 da Constituição Federal que contempla o princípio da moralidade administrativa.

Ademais, um dos ângulos relevantes da boa-fé se relaciona com o princípio que veda a contrariedade e impossibilita o venire contra factum proprium - idéia esta consagrada no direito brasileiro moderno. Assim, não se pode esquecer que o Supremo Tribunal Federal já se manifestou acerca da validade da inclusão de cláusula compromissória em contrato celebrado entre a Administração Pública e um particular. O leading case em questão se trata do julgamento, ocorrido em 1973, que envolveu a União e o Espólio Henrique Lage e de Renaud Lage ${ }^{72}$ - já tantas vezes mencionado pelos autores aqui citados que tratam do assunto. Nesse caso, a ação ajuizada

tornou-se possível resolver o mérito "quando o juiz acolher ou rejeitar o pedido do autor [...]”, seja parcial ou integralmente.

${ }_{71}^{71}$ MARTINS, Pedro Batista Martins. A arbitragem e o mito da sentença parcial. p. 283-284

${ }^{72}$ Agravo de Instrumento no 52.181 - GB, Relator Min. Bilac Pinto, RTJ 68/382-397 
visava o recebimento de indenização fixada por meio de um procedimento arbitral, em razão da incorporação pela União ao patrimônio nacional dos bens e direitos das empresas da chamada Organização Lage e do referido Espólio, sob fundamento da existência de estado de guerra. A Suprema Corte, por unanimidade, rechaçou os questionamentos existentes quanto à possibilidade do Estado pactuar a submissão ao juízo arbitral. A Administração não pode ignorar suas condutas anteriores e desconhecer as orientações que transmitira ao particular ou as exigências a ele impostas. Há, portanto, um dever de coerência com o futuro, que atinge o próprio princípio da moralidade ${ }^{73}$.

\subsubsection{O alcance da decisão}

Em que pese todo o exposto acima, ressalta-se que a cláusula compromissória é autônoma. Isto significa que sua validade não depende da validade do contrato em que foi inserida. Da mesma forma, sua nulidade não implica a nulidade do contrato que lhe deu origem.

No acórdão referente ao contrato para a construção e o estabelecimento do Museu Guggenheim, embora o Tribunal tenha entendido pela nulidade da cláusula arbitral, deve-se salientar que não foi este o motivo da nulidade do contrato como um todo. Como visto, a nulidade da cláusula de juízo arbitral não desnatura o pacto, mantendo-se a validade do contrato, haja vista o que determina o art. $8^{\circ}$ da Lei de Arbitragem. No caso, contudo, foram constatadas outras ilegalidades no ajuste - que não guardam qualquer relação com o tema do presente trabalho e, por isso, não foram apreciadas - que impediram sua celebração.

\footnotetext{
73 JUSTEN FILHO, Marçal. Algumas considerações acerca das licitações em matéria de concessão de serviços públicos. Disponível em <http://direitodoestado.com/revista/REDAE-1FEVEREIRO-2005-MAR\%C3\%87AL\%20JUSTEN.pdf >. Acesso em 17 out. 2007.
} 
Atente-se, por fim, que no que se refere à convenção de arbitragem, o alcance desta decisão fica restrito aos contratos administrativos sujeitos ao regime jurídico da Lei $n^{\circ}$ 8.666/93. Não se presta como precedente em relação a matérias regidas por regime jurídico específico, resultantes de outros diplomas legais $^{74}$.

74 VALENÇA FILHO, Clávio. Validade e eficácia da convenção de arbitragem em contratos administrativos: a ótica judiciária. p. 441 


\section{Conclusão}

Ao término do presente trabalho, não se pode mais ignorar as vantagens oferecidas pela escolha da arbitragem como meio de solução extrajudicial de controvérsias. Demonstrou-se que a arbitragem é a forma eficaz e a mais indicada para solucionar questões surgidas no âmbito das relações comerciais e a essas relativas, sobretudo em função da especificidade das matérias envolvidas e da celeridade do procedimento. Ademais, nos contratos celebrados entre pessoas de países distintos, a arbitragem internacional é frequentemente o único mecanismo aceitável, visto que cada parte desconfia dos tribunais que não o seu. Tanto a lei material como a processual diferem de um ordenamento para o outro, assim como a especialidade, a neutralidade e a rapidez dos respectivos tribunais. $\mathrm{Na}$ arena internacional, as vantagens incluem, especialmente, a possibilidade das partes escolherem os árbitros, a flexibilidade procedimental e a maior facilidade na execução de sentenças arbitrais em jurisdições diferentes do local em que foi proferida.

Os direitos indisponíveis limitam o recurso a esse mecanismo, mas a definição do que seja ou não direito indisponível requer cuidado. Isto porque a arbitrabilidade de controvérsias comporta a feição subjetiva e objetiva. Tendo em vista que o Supremo Tribunal Federal já se manifestou acerca da capacidade dos entes da Administração Pública para se submeter à arbitragem, eventuais limitações em se tratando de contratos administrativos residem, sobretudo, no objeto da matéria, pois não é pacífica a natureza dos direitos envolvidos nos contratos administrativos.

No decorrer deste trabalho, mostrou-se ainda que a idéia de que os contratos administrativos envolvem sempre direitos indisponíveis e, portanto, inarbitráveis, já foi ultrapassada na doutrina. $\mathrm{O}$ entendimento dos tribunais, contudo, é vacilante. Ora se verifica uma posição reticente do 
Judiciário que persiste na confusão entre o princípio da indisponibilidade do interesse público e da disponibilidade do patrimônio da Administração para negar a validade do pacto arbitral em contratos administrativos. Outras vezes, contudo, não escapa ao Judiciário entusiasta que se tratam de conceitos distintos e contornam tal problemática reconhecendo a incidência do princípio da indisponibilidade apenas em se tratando de interesses públicos primários.

Ante todo o exposto, a resposta à questão apresentado no início do presente é positiva: é válida a cláusula arbitral em contrato administrativo. Sendo o objeto do contrato administrativo um direito patrimonial disponível, nada obsta a inserção de uma cláusula arbitral no ajuste. A própria Lei de Arbitragem em seu art. $1^{\circ}$ autoriza todas as pessoas capazes a contratar cláusulas de arbitragem desde que os direitos envolvidos não sejam inapropriáveis, quer do Estado ou do particular.

Além disso, a existência de contraprestação financeira no contrato não deixa a menor dúvida quanto à disponibilidade dos direitos envolvidos visto que o Estado não atua, em absoluto, com ius imperium - apenas transaciona como qualquer outra pessoa.

$\mathrm{O}$ art. 54 da Lei $\mathrm{n}^{\circ}$ 8.666/93 dispõe que os contratos administrativos regem-se pelas suas cláusulas e preceitos de direito público, e os princípios de direito privado podem ser-lhes aplicados de maneira supletiva. Isto também reforça a possibilidade das partes em um contrato administrativo submeterem eventuais controvérsias à arbitragem.

Nos contratos administrativos, esse meio de solução de controvérsias concretiza o princípio da eficiência, constante do art. 37 da Constituição, que deve pautar todos os atos do Poder Público. Este princípio impõe aos agentes estatais um dever de otimização dos recursos públicos (buscar o 
melhor resultado, despendendo o mínimo de recursos) e um dever de eficácia administrativa (os fins que a Administração almeja devem ser realizados com o menor custo econômico possível).

As premissas atuais que orientam as contratações públicas, em especial quando a Administração contrata com particulares, demonstram a quebra de antigos paradigmas. Não se trata mais de conceber o Estado como prestador de serviços, busca-se um Estado que estimula e ajuda a iniciativa privada, bem como a redução do tamanho desse Estado visando a uma maior eficiência.

Em decorrência principalmente do elevado custo e porte dos empreendimentos, o Estado não pode dispensar a colaboração e o aporte de capital privado. Torna-se imperativo, portanto, flexibilizar-se a relação contratual, priorizando o equilíbrio de interesses das partes. O Estado não pode concorrer com as empresas privadas sempre em posição de privilégio, sob pena de tornar-se ainda mais ineficiente ao inviabilizar tais ajustes. Tal como no direito privado, o tratamento igualitário dos contratantes ganha destaque - sem que, com isso, se abra mão das cláusulas exorbitantes que caracterizam e distinguem os contratos administrativos. Nesse novo contexto, em consonância com a tendência internacional e, observando os princípios jurídicos da igualdade, legalidade, boa-fé, justiça e do pacta sunt servanda, a Administração é levada a buscar meios mais rápidos para solucionar controvérsias oriundas de seus contratos cujo objeto sejam direitos patrimoniais disponíveis.

Note-se que o Estado, ao aceitar e promover, ele próprio a solução extrajudicial de seus litígios através do mecanismo da arbitragem, contribui para reforçar a qualidade da democracia e aprofundar a cidadania. Ademais, interessa à coletividade garantir relações contratuais equilibradas, pautadas no princípio da boa-fé e assegurar uma solução rápida e eficiente para os 
conflitos, inclusive os que envolvem entes da Administração Pública. E esses são atributos do procedimento arbitral.

Apesar dos avanços da prática arbitral no Brasil desde o advento da Lei de Arbitragem, há temas que ainda provocam divergência. Decisões judiciais como a proferida no caso do Museu Guggenheim - analisado no capítulo anterior -, contribuem para denegrir a imagem que o Brasil possui na comunidade internacional. Como visto, o Tribunal de Justiça do Rio de Janeiro errou, pois a indisponibilidade do interesse público não se contrapõe necessariamente à disponibilidade dos direitos patrimoniais da Administração. Tampouco se excluem mutuamente a regra de instituição de foro exclusivo e o pacto arbitral. Por fim, é possível harmonizar o princípio da publicidade que rege os atos administrativos com o procedimento arbitral.

Cabe aqui uma outra observação: a arbitragem não esvazia o poder do Judiciário. O Judiciário é uma máquina muito cara e um aparato democrático muito pesado para resolver questões comerciais, de direitos disponíveis. O Judiciário é para liberdade, para a proteção da vida, da dignidade da pessoa humana. Essas são questões inarbitráveis.

Ademais, o número significativo de processos a serem julgados não permite ao juiz dedicar-se a um caso complexo. Além disso, a especificidade de determinadas questões na área empresarial escapa ao conhecimento do juiz, que não é obrigado a conhecer, por exemplo, contratos de joint ventures ou entender de derivativos ou instalação de parques industriais.

Assim, a compreensão de que são válidas as cláusulas compromissórias inseridas em contratos administrativos, cujo objeto seja 
direito patrimonial disponível, é fundamental para o desenvolvimento do país. 


\section{Bibliografia}

ARAUJO, Nadia de. Direito internacional privado: teoria e prática brasileira. $3^{a}$ ed. atualizada e ampliada. Rio de Janeiro: Renovar, 2006. p. 461-475.

BINENBOJM, Gustavo. Temas de direito administrativo e constitucional artigos e pareceres. Rio de Janeiro: Renovar, 2008. p. 137-141.

BRINDEIRO, Geraldo. Apud ALVES, André Camerlingo. A constitucionalidade da lei de arbitragem: jurisprudência comentada. In: Repertório de Jurisprudência IOB. Vol. III, nº 17- set. 2004. p. 500-512.

CARMONA, Carlos Alberto. Considerações sobre a cláusula compromissória e a cláusula de eleição de foro. In: LEMES, Selma Ferreira; CARMONA, Carlos Alberto; MARTINS, Pedro Batista (coord.). Arbitragem: estudos em homenagem ao Prof. Guido Fernando da Silva Soares. São Paulo: Atlas, 2007. p. 33-46.

CASELLA, Paul B. (org.) Arbitragem: lei brasileira e praxe internacional. $2^{\text {a }}$ ed. rev. e ampl. São Paulo: LTr, 1999.

DI PIETRO, Maria Sylvia Zanella. Direito administrativo. $11^{\mathrm{a}}$ ed. São Paulo: Atlas, 1999. p. 1-93.

DOLINGER, Jacob e TIBURCIO, Carmen. Arbitragem comercial internacional - parte II. Rio de Janeiro: Renovar, 2003.

FIGUEIREDO, Lucia Valle. Curso de direito administrativo. $6^{\mathrm{a}}$ ed. São Paulo: Malheiros, 2003.

GAMA e SOUZA JR, Lauro. Arbitragem comercial internacional: estudo comparativo entre o sistema jurídico da província de Québec (Canadá) e o novo direito brasileiro de arbitragem. In: Revista de Direito da Procuradoria Geral do Rio de Janeiro. vol. 50. [S.I.: s.n.]. p. 213-253.

GAMA e SOUZA JR, Lauro. Sinal verde para a arbitragem nas parcerias público-privadas (a construção de um novo paradigma para os contratos entre o Estado e o investidor privado). In: Revista Brasileira de Arbitragem. vol. 8. out-dez 2005. p. 7-42.

GRAU, Eros Roberto. Apud Arbitragem e contrato administrativo. Revista Trimestral de Direito Público. n. 32, p. 20 
JURUENA, Marcos; FIGUEREDO, Diogo de. In: Revista de Direito Administrativo. vol. 236, p. 216-217

JUSTEN FILHO, Marçal. Curso de direito administrativo. São Paulo: Saraiva, 2005. p. 11-91; 485-524.

LEE, João Bosco. O princípio da confidencialidade na arbitragem comercial internacional. In: MENEZES, Wagner (org.). $O$ direito internacional $e o$ direito brasileiro: homenagem a José Francisco Rezek. Ijuí: Ed. Unijuí, 2004 p. 732-740.

LEVEL, Patrícia. Apud Lee, João Bosco. O conceito de arbitrabilidade nos países do Mercosul. In: Revista de Direito Bancário, do Mercado de Capitais e da Arbitragem. Ano 3, $\mathrm{n}^{\circ}$ 8. São Paulo: Editora Revista dos Tribunais, abr./jun. 2000.

LOBO, Carlos Augusto da Silveira. Uma introdução à arbitragem internacional. In: ALMEIDA, Ricardo (coord). Arbitragem interna $e$ internacional: questões de doutrina e da prática. Rio de Janeiro: Renovar, 2003. p. 8-9

MEDEIROS, Suzana Domingues. Arbitragem envolvendo o estado no direito brasileiro. In: Revista de Direito Administrativo. vol. 233, jun./set. 2003.

MEIRELLES, Hely Lopes. Licitação e contrato administrativo. $10^{\mathrm{a}} \mathrm{ed}$. atual. São Paulo: Editora Revista dos Tribunais, 1991. p. 182

MELLO, Celso Antonio Bandeira de. Curso de direito administrativo. São Paulo: Malheiros, 1995.

MOREIRA NETO, Diogo de Figueiredo. Mutações do direito administrativo. $3^{\text {a }}$ ed. rev. e ampl. Rio de Janeiro: Renovar, 2007. p. 273288, 405-470.

MOREIRA NETO, Diogo de Figueiredo. Apud. LEMES, Selma Ferreira In: Anais das palestras proferidas em 2004 na Secretaria Pro Tempore do Conselho de Câmaras de Comércio do Mercosul. Rio de Janeiro: Confederação Nacional do Comércio, 2004.

PEREIRA, César A. Guimarães. Arbitragem e a administração pública comentários ao acórdão do STJ no REsp 612. 439/RS ("Caso AES Uruguaiana"). Revista Brasileira de Arbitragem. v. 12. Curitiba: Comitê Brasileiro de Arbitragem, out./dez. 2006. p. 119 
TÁCITO, Caio. Apud Temas de direito público. v.3. Rio de Janeiro: Renovar, 2002. p. 83-88.

TALAMINI, Eduardo. Apud PEREIRA, César A. Guimarães. Arbitragem e a administração pública - comentários ao acórdão do STJ no REsp 612. 439/RS ("Caso AES Uruguaiana"). Revista Brasileira de Arbitragem. no 12. Curitiba: Comitê Brasileiro de Arbitragem, out./dez. 2006. p. 98-120.

TIBURCIO, Carmen. O desenvolvimento da arbitragem no mundo e no Brasil. In: MENEZES, Wagner (org.). O direito internacional e o direito brasileiro: homenagem a José Francisco Rezek. Ijuí: Ed. Unijuí, 2004 p. 741-764.

VALENÇA FILHO, Clávio. Validade e eficácia da convenção de arbitragem em contratos administrativos: a ótica judiciária. In: LEMES, Selma Ferreira; CARMONA, Carlos Alberto; MARTINS, Pedro Batista. Arbitragem: estudos em homenagem ao Professor Guido Fernando da Silva Soares. São Paulo: Atlas, 2007. p. 436-453.

VALLE, Martim Della. Considerações sobre os pressupostos processuais em arbitragem. Revista Brasileira de Arbitragem. $\mathrm{n}^{\circ}$ 12. Curitiba: Comitê Brasileiro de Arbitragem, out./dez. 2006. p. 7-30.

WALD, Arnoldo. A evolução do direito e a arbitragem. In: LEMES, Selma Ferreira; CARMONA, Carlos Alberto; MARTINS, Pedro Batista (coord.). Arbitragem: estudos em homenagem ao Prof. Guido Fernando da Silva Soares. São Paulo: Atlas, 2007. p. 454-463. 